\title{
PRAVNI I INSTITUCIONALNI OKVIR INTEGRACIJE MIGRANATA U HRVATSKO DRUŠTVO
}

\author{
UDK: 341.43:323.111(497.5)
}

DOI: $10.31141 /$ zrpfs.2020.57.137.707

Izvorni znanstveni rad

Primljeno: 10. III. 2020

Dobro je poznato kako je fenomen migracija postao iznimno relevantan u posljednjih nekoliko desetljeća. Migrantska kriza u Europi je posebice od 2015. godine rezultirala brojnim raspravama o migracijama, izbjeglicama, integraciji i sličnim pitanjima, te je stoga jedan od ciljeva ovog rada dati odgovarajući doprinos profesionalnoj i javnoj debati na području integracije migranata u hrvatsko društvo. Rad je koncipiran u pet dijelova. Nakon uvodnog dijela, u drugom dijelu rada izlaže se teorijski okvir koncepta integracije migranata, odnosno prikazuju se pokušaji (još uvijek neuspješnog) iznalaženja jedinstvene definicije pojma integracije migranata. Slijedi treći dio, u kojemu se daje pregled pravnog okvira Republike Hrvatske na području integracije migranata. U tom kontekstu, navode se relevantne odredbe Ustava Republike Hrvatske, relevantni ratificirani međunarodni ugovori, te odgovarajući zakoni i podzakonski propisi, kao i relevantna praksa Ustavnog suda Republike Hrvatske. Imajući u vidu da je Republika Hrvatska harmonizirala svoje zakonodavstvo s acquis communaitaireom Europske unije i članica je Europske unije, u radu se posebna pozornost poklanja prikazu okvira Europske unije za integraciju migranata. Četvrti dio rada bavi se institucionalnim okvirom Republike Hrvatske za integraciju migranata, pri čemu se naglašava kako je područje integracije migranata, na temelju zakonodavnog i regulatornog integracijskog okvira, područje koje je u nadležnosti nekoliko ministarstava (na čelu s Ministarstvom unutarnjih poslova), ureda, povjerenstava, a značajnu ulogu u ovom području svakako imaju i brojne nevladine organizacije. Konačno, u petom i ujedno zaključnom dijelu rada navode se preporuke za daljnji razvoj integracijske politike Republike Hrvatske.

Ključne riječi: integracija, migranti, društvo, Republika Hrvatska

\section{UVOD}

Iako migracije i s njima povezani procesi imaju dugu povijest, dobro je poznato kako je ovo područje postalo iznimno relevantno u Europi tek u posljednjih nekoliko desetljeća, odnosno točnije tek u posljednja dva desetljeća. Intenziviranje migracija

1 Izv. prof. dr. sc. Anita Blagojević, Stjepana Radića 13, 31000 Osijek, e-mail: ablagoje@pravos.hr 
i veliki priljev migranata ${ }^{2}$ koji su posebice obilježili razdoblje između 2015. i 2106. godine paralelno su pratile sve brojnije rasprave o migracijama, izbjeglicama, integraciji i sličnim pitanjima, vođene u raznim sferama političkog i općedruštvenog života. Pri tome, svjesni činjenice kako su migracije imale i imaju utjecaj na različite sfere života (ekonomsku, kulturnu, političku, geografsku, antropološku, povijesnu, religioznu itd.), jasno je kako fenomen migracija predstavlja multidisciplinarno područje istraživanja. Jedan od ciljeva ovog rada stoga je dati odgovarajući doprinos profesionalnoj i javnoj debati na području integracije migranata u hrvatsko društvo.

Rad je koncipiran u pet dijelova. Nakon uvodnog dijela, u drugom dijelu rada izlaže se teorijski okvir koncepta integracije migranata, odnosno prikazuju se pokušaji (još uvijek neuspješnog) iznalaženja jedinstvene definicije pojma integracije migranata. Slijedi treći dio, u kojemu se daje pregled pravnog okvira Republike Hrvatske na području integracije migranata. U tom kontekstu, navode se relevantne odredbe Ustava Republike Hrvatske, relevantni ratificirani međunarodni ugovori, te odgovarajući zakoni i podzakonski propisi, kao i relevantna praksa Ustavnog suda Republike Hrvatske. Imajući u vidu da je Republika Hrvatska harmonizirala svoje zakonodavstvo s acquis communaitaireom Europske unije i članica je Europske unije, u radu se posebna pozornost poklanja prikazu okvira Europske unije za integraciju migranata. Četvrti dio rada bavi se institucionalnim okvirom Republike Hrvatske za integraciju migranata, pri čemu se naglašava kako je područje integracije migranata, na temelju zakonodavnog i regulatornog integracijskog okvira, područje koje je u nadležnosti nekoliko ministarstava (na čelu s Ministarstvom unutarnjih poslova), ureda, povjerenstava, a značajnu ulogu u ovom području svakako imaju i brojne nevladine organizacije. Konačno, u petom i ujedno zaključnom dijelu rada navode se preporuke za daljnji razvoj integracijske politike Republike Hrvatske.

\section{INTEGRACIJA MIGRANATA U DRUŠTVO - TEORIJSKI KONCEPT}

Koncept integracije migranata u društvo bez ikakve je sumnje višedimenzionalan i u najmanju ruku ambiciozan, a u krajnju ruku kaotičan, kao što to navodi Robinson (,riječ koju upotrebljavaju mnogi, ali ju većina razumije različito“). ${ }^{3}$ Stoga i ne čudi činjenica da je pojam integracije migranata pojam oko kojega do danas nije postignuta jedinstvena definicija.

2 Iako se pojmovi „migrant“ i ,izbjeglica“ vrlo često smatraju sinonima, riječ je o dvije kategorija osoba. Temeljem čl. 1. Konvencije o statusu izbjeglica iz 1951., izbjeglica je svaka osoba koja se zbog osnovanog straha od progona zbog svoje rase, vjere, nacionalnosti, pripadnosti nekoj društvenoj skupini ili političkog mišljenja, ne može ili ne želi vratiti u svoju državu podrijetla. S druge strane, ne postoji jedinstvena definicija pojma „migrant“, no u ovom radu pod pojmom „migrant“ podrazumijevamo osobu koja svjesno odluči otići iz svoje zemlje u potrazi za boljim životom.

3 Robinson, V., „Defining and measuring successful refugee integration“, u: ECRE, Proceedings of ECRE International Conference on Integration of Refugees in Europe, Antwerpen, November 1998, str. 118, dostupno na: http://repesitory.forcedmigration.org $>$ pdf, pristupljeno: 10. rujna 2019. 
Unatoč tome što znanstvene studije na području integracije migranata imaju relativno dugu povijest, ${ }^{4}$ a i danas je ovo područje (možda i više nego ikada prije) predmetom brojnih studija i debata, do danas nije postignut opći konsenzus oko definicije ovog pojma. Razlog tome leži i u činjenici da su pojedini autori ovom pojmu pristupali iz različitih perspektiva, odnosno u svojim su se istraživanjima fokusirali na pojedine dimenzije integracije. Tako Esser naglašava kako se svaka teorija o integraciji migranata odnosi na tri različita, ali međusobno ovisna aspekta: prvi, koji obuhvaća socijalnu integraciju migranata kao individualnih aktera u društveni sustav; drugi, koji obuhvaća pojavu određenih društvenih struktura, posebno u odnosu na obrasce socijalne nejednakosti i socijalne diferencijacije, te treći, koji se odnosi na socijalnu integraciju cijelog društva. ${ }^{5}$ Za Heckmanna i Bosswicka integracija je proces inkluzije migranata u institucije i odnose društva doseljenja. ${ }^{6}$ Klarenbeek definira integraciju kao krajnje stanje koje treba funkcionirati kao evaluativni standard za istraživanje integracije: društvo u kojemu nema socijalnih granica između „legitimnih članova“, ili ,insajdera“, i „,nelegitimnih članova“, ili ,autsajdera“.7 Jednostavnu i u isto vrijeme vrlo korisnu definiciju integracije daje Penninx, koji definira integraciju kao „,proces postajanja prihvaćenim dijelom društva“. 8

Izvan akademskih krugova definiciju pojma integracije možemo pronaći u raznim dokumentima različitih organizacija. Tako, primjerice, Europsko vijeće za izbjeglice i raseljene osobe (European Council on Refugees and Exiles - ECRE), mreža nevladinih organizacija koje pomažu izbjeglicama, definira integraciju kao proces promjene koji je: 1) dinamičan i dvosmjeran, jer stvara obveze i na strani receptivnog društva, i na strani subjekta integracije; 2) dugoročan, jer započinje trenutkom ulaska migranta u zemlju, a završava kada migrant postane aktivan član društva iz pravne, socijalne, ekonomske, obrazovne i kulturne perspektive, te 3 )

${ }^{4}$ Penninx i Garcés-Mascarenas navode kako znanstvene studije o procesu smještaja pridošlica u društvo prihvaćanja imaju dugu povijest i kako je ovo područje popularizirano od strane Čikaške škole urbane sociologije (Chicago School of urban sociology) početkom 20. stoljeća. Penninx, R., GarcésMascarenas, B., ,The Concept of Integration as an Analytical Tool and as a Policy Concept“, u: GarcésMascarenas, B., Penninx, R. (Editors), Integration Process and Policies in Europe. Context, Levels and Actors, IMISCOE Researches Series, Springer Open, 2016., str. 11.

5 Esser, H., Does the New Immigration Require a New Theory of Intergenerational Integration?, Working paper, Mannheim: MZES 2003, str. 6, dostupno na: http://citeseerx.ist.psu.edu/viewdoc/downlo ad?doi=10.1.1.197.2189\&rep=rep1\&type=pdf, pristupljeno: 10. rujna 2019.

6 Heckmann, F., Bosswick, W., Integration of Migrants: Contribution of Local and Regional Authorities, European Foundation for the Improvement of Living and Working Conditions, 2006., str. 1, dostupno na: https://www.researchgate.net/publication/297802930_Integration_of_Migrants_ Contribution_of_Local_and_Regional_Authorities, pristupljeno: 10. rujna 2019.

7 Klarenbbek, L. M., „Reconceptualising 'integration as a two-way process'“, Migration studies, mnz033, 2019., str. 2, dostupno na: https://doi.org/10.1093/migration/mnz033, pristupljeno: 10. rujna 2019.

8 Penninx navodi kako je ova jednostavna definicija otvorena u dva aspekta: $\mathrm{s}$ jedne strane, naglasak je na procesu integracije, a ne na definiranju kraja procesa, a s druge strane, definicija ne navodi partikularne zahtjeve za prihvaćanje u društvo od strane društva prihvaćanja. Penninx, R., „Integration of Migrants: Economic, Social, Cultural and Political Dimensions", The new demographic regime, Chapter VIII, str, 141, dostupno na: https://www.researchgate.net/publication/254920820_Integration_of_migrants_ Economic_social_cultural_and_political_dimensions, pristupljeno: 10. rujna 2019. 
multidimenzionalan, jer se odnosi na stvaranje uvjeta za participaciju migranata u svim aspektima ekonomskog, društvenog, kulturnog, građanskog i političkog života receptivnog društva, kao i na percepciju migranata o njihovoj prihvaćenosti u društvu. ${ }^{9}$ Vijeće Europe definira integraciju kao dvosmjeran i neprekidan proces, koji ovisi o konstruktivnom trostranom angažmanu vlasti, društva dobrodošlice (posebice civilnog društva) i migranata". ${ }^{10}$

U okviru Europske unije Europska komisija je, primjerice, 2003. definirala integraciju kao dvosmjerni proces koji se temelji na obostranim pravima i korespondirajućim obvezama osobe koja je državljanin treće države, a ima legalan boravak u receptivnoj državi, s jedne strane, te receptivnog društva, s druge strane. ${ }^{11}$ Ipak, valja napomenuti da iako se o integraciji uobičajeno govori kao o dvosmjernom procesu u koji su uključene dvije strane, odnosno migranti i receptivno društvo, u novije se vrijeme predlaže pristup prema kojemu bi integracija uključivala i treću stranu, odnosno zemlju podrijetla migranata. ${ }^{12} \mathrm{U}$ tom smislu se prvim odvjetnikom za uključenost zemlje podrijetla kao treće strane procesa integracije smatra Kirişci koji u svom radu iz 2008. navodi da zemlje podrijetla migranata imaju društveni kapital, iskustvo i interes kojim mogu doprinijeti Europskoj uniji u njezinu nastojanju da razvije bolje integracijske politike. ${ }^{13}$ Navedena promjena paradigme rezultirala je odgovarajućim promjenama u dokumentima Europske unije, tako da se, primjerice, u Europskom programu za integraciju državljana trećih država iz 2011. govori o važnosti „treće strane“, odnosno zemlje podrijetla, koja može doprinijeti procesu integracije na tri načina: 1) u pripremi integracije već prije odlaska migranta; 2) u podršci migrantima dok su u Europskoj uniji, te 3) u pripremi privremenog ili trajnog povratka migranata. ${ }^{14}$

U nedostatku jedinstvene definicije pojma integracije, brojna istraživanja procesa integracije fokusiraju se na postojanje različitih dimenzija integracije, koje

9 European Council of Refugees and Exiles, Position on the Integration of Refugees in Europe, 2002., str. 4, dostupno na: https://www.ecre.org/wp-content/uploads/2016/07/ECRE-Position-on-theIntegration-of-Refugees-in-Europe_December-2002.pdf, pristupljeno: 9. rujna 2019.

10 Council of Europe, Human rights aspects of immigrant and refugee integration policies, Issue Paper published by the Special Representative of the Secretary General on migration and refugees, 2019 ., str. 7, dostupno na: https://rm.coe.int/168093de2c, pristupljeno: 10. rujna 2019.

11 Communication from the Commission to the Council, the European Parliament, the European Economic and Social Committee and the Committee of the Regions on immigration, integration and empolyment, COM (2003) 336 final, dostupno na: https://eur-lex.europa.eu/legal-content/EN/TXT/HTM L/?uri=CELEX:52003DC0336\&from=EN, pristupljeno: 9. rujna 2019.

12 Garcés-Mascarenas, B., Penninx, R., „Introduction: Integration as a Three-Way Process Approach?“, u: Garcés-Mascarenas, B., Penninx, R. (Editors), Integration Process and Policies in Europe. Context, Levels and Actors, op. cit. (bilj. 3), str. 1.

13 Kirişci, K., „Three Way Approach“ to Meeting the Challenges of Migrant Incor-poration in the European Union: Reflections from a Turkish Perspective, CARIM Research Reports 2008/03, European University Institute, Robert Schuman Centre for Advanced Studies, 2008., str. 22.

14 Communication from the Commission to the European Parliament, the Council, the European Economic and Social Committee of the Regions: European Agenda for the Integration of ThirdCountry Nationals, COM (2011), dostupno na: https://www.km.gov.lv/uploads/ckeditor/files/ Sabiedribas_integracija/Treso_valstu_pilsoni/Dokumenti/Eiropas\%20programmma\%20TVP\%20 integr\%C4\%81cijai\%202011.pdf, pristupljeno: 15. rujna 2019. 
sadrže različite indikatore integracijskog procesa za mjerenje stupnja prihvaćenosti migranata u receptivno društvo. Penninx i Garcés-Mascarenas navode tri (temeljne) dimenzije integracijskog procesa: 1) pravno-političku, koja uključuje različita statusna i politička prava; ${ }^{15}$ 2) socijalno-ekonomsku, koja uključuje socijalni i ekonomski položaj rezidenata, bez obzira na njihovo državljanstvo, ${ }^{16}$ te 3 ) kulturnoreligijsku dimenziju, koja uključuje područje percepcije i prakticiranja različitosti u kulturnom i religioznom pogledu u društvu države primateljice. ${ }^{17}$ Za Heckmanna i Bosswicka integracija ima sljedeće dimenzije: 1) strukturnu, koja uključuje kombinaciju pravno-političkih i socijalno-ekonomskih elemenata; 2) kulturnu; 3) interaktivnu, koja uključuje prihvaćenost i uključenost migranata u primarne odnose i društvene mreže receptivnog društva, te 4) identifikacijsku, koja uključuje subjektivni osjećaj pripadanja i identifikaciju s određenim skupinama u društvu. ${ }^{18}$

Unatoč nepostojanju jedinstvene definicije integracije, ono što je sigurno kod definiranja integracije jest da je to proces (i to višedimenzionalan i dugotrajan) prihvaćanja migranata u (receptivno) društvo. Također, to je proces čiji je cilj integrirati migrante u društvo tako da imaju priliku za samostalan, siguran i dostojanstven život. Iako ne postoji jedinstveni model za ostvarivanje ovog cilja, načini na koji pojedine države ostvaruju integraciju mogu se klasificirati u nekoliko temeljnih modela. Prema Institutu za migracije i narodnosti, temeljni su modeli integracije modeli potpune isključenosti, djelomične isključenosti, te asimilacijski i pluralistički model.${ }^{19}$ Model potpune isključenosti jest model u kojemu je migrant definiran kao stranac ili netko tko ne pripada u određenu zemlju i/ili zajednicu, odnosno model koji karakteriziraju ad hoc odgovori na konkretan problem, te je kao takav prisutan više u teoriji nego u praksi. ${ }^{20}$ Model djelomične isključenosti temelji se na participaciji migranata u pojedinim segmentima društva (ponajprije na tržištu rada), zbog čega je uloga migranata reducirana na ekonomsko područje, dok su u ostalim područjima političkog, socijalnog i kulturnog života isključeni iz participacije. ${ }^{21}$ Asimilacijski model podrazumijeva uključenost migranata $u$ receptivno društvo unilateralnim procesom ,adaptacije“, pri čemu se od migranata ne očekuje da ističu svoju kulturnu, jezičnu ili religioznu pripadnost, u cilju što

15 Pravno-politička dimenzija obuhvaća, primjerice, prava vezana uz boravak, stjecanje državljanstva, spajanje obitelji, političku participaciju itd.

16 Socijalno-ekonomska dimenzija obuhvaća, primjerice, prava vezana uz tržište rada, uključujući pravo na rad, pravo na stanovanje, obrazovanje, zdravstvenu zaštitu itd.

17 Penninx, R., Garcés-Mascarenas, B., The Concept of Integration as an Analytical Tool and as a Policy Concept, op. cit. (bilj. 3), str. 14-16.

18 Heckmann, F., Bosswick, W., Integration of Migrants: Contribution of Local and Regional Authorities, op. cit. (bilj. 5), str. 9-11.

19 Institute for Migration and Ethnic Studies, Integration of Migrants in the European Union with Reference to Croatia: Position Paper of the Institute for Migration and Ethnic Studies, 2016., str. 4, dostupno na: http://www.imin.hr/en/c/document_library/get_file?uuid=23cb77ac-e5d4-4f1e-8fceb2e040512833\&groupId=10156, pristupljeno: 11 . rujna 2019.

20 Ibid., str. 5.

21 Ovaj model bio je tipičan za zapadnoeuropske zemlje u razdoblju sredine i druge polovice 20. stoljeća. Ibid. 
jednostavnijeg ,,spajanja“ $s$ većinskom populacijom..$^{22}$ Konačno, pluralistički model shvaća pripadnike migrantskih skupina kao etničke zajednice koje se razlikuju od većinske populacije po jeziku, kulturi, običajima i nekim drugim karakteristikama, pri čemu se od migranata očekuje da prihvate temeljne društvene vrijednosti receptivnog društva, a u isto im se vrijeme jamči njihovo pravo da budu različiti. ${ }^{23}$ U pogledu zastupljenosti pojedinih modela u europskim zemljama, valja naglasiti kako je u većini zemalja integracijska politika kombinirana s asimilacijskim i pluralističkim modelom. ${ }^{24}$

\section{INTEGRACIJA MIGRANATA U HRVATSKO DRUŠTVO - PRAVNI OKVIR}

Pravni okvir Republike Hrvatske za integraciju migranata čine relevantne odredbe Ustava Republike Hrvatske, ${ }^{25}$ relevantni ratificirani međunarodni ugovori, te odgovarajući zakoni i podzakonski propisi. Imajuću u vidu da je Republika Hrvatska harmonizirala svoje zakonodavstvo s acquis communaitaireom Europske unije i članica je Europske unije, u nastavku rada bit će prikazan i kratak prikaz okvira Europske unije za integraciju migranata.

\subsection{Ustavni okvir za integraciju migranata}

Općenito se može istaknuti kako je važnost ustavnih jamstava ljudskih prava i temeljnih sloboda naglašena u Ustavu Republike Hrvatske kako mjestom koje relevantno poglavlje ima u strukturi ustavnog teksta, tako i opsegom koji navedena jamstva imaju u cjelini ustavnog teksta. ${ }^{26}$ Treća cjelina Ustava podijeljena je u tri odjeljka: 1) Zajedničke odredbe, 2) Osobne i političke slobode i prava, te 3) Gospodarska, socijalna i kulturna prava.

Temeljno pravno načelo o jednakosti svih ljudi, kako državljana, tako i stranaca, u pogledu korištenja njihovim pravima sadržano je u čl. 14. Ustava, kojim se zabranjuje diskriminacija ljudskih bića po bilo kojoj osnovi, odnosno neovisno o rasi, boji kože, spolu, jeziku, političkom ili drugom uvjerenju, nacionalnom ili socijalnom podrijetlu, imovini, rođenju, naobrazbi, društvenom položaju ili drugim osobinama. Ovo načelo dodatno je naglašeno u drugom stavku istog članka prema

22 Asimilacijski model bio je tipičan za početak 20. stoljeća, a od europskih država bio je zastupljen u Francuskoj, te nakon Drugoga svjetskog rata u Velikoj Britaniji, Kanadi i Australiji. Međutim, s vremenom je napušten i zamijenjen pluralističkim modelom. Ibid.

23 Ibid., str. 6.

24 Ibid.

25 Ustav Republike Hrvatske, Narodne novine br. 56/90., 135/97., 8/98., 113/00., 124/00., 28/01., 41/01., 55/01., 76/10., 85/10., 5/14.

26 Treće poglavlje Ustava nosi naziv Zaštita ljudskih prava i temeljnih sloboda i slijedi odmah nakon Izvorišnih osnova i Temeljnih odredbi, a popis ustavnih jamstava ljudskih prava i sloboda obuhvaća više od trećine ustavnog teksta. 
kojemu su svi pred zakonom jednaki. U skladu s čl. 16. Ustava, ljudska prava mogu se ograničiti samo zakonom, i to u cilju zaštite sloboda i prava drugih ljudi, te zaštite pravnog poretka, javnog morala i zdravlja, s tim da svako takvo ograničenje mora biti razmjerno naravi potrebe za ograničenjem u svakom pojedinom slučaju.

Drugim odjeljkom III. glave Ustava zajamčene su osobne i političke slobode i prava, uključujući pravo na život, slobodu i integritet osobnosti, zabranu mučenja i prisilnog rada, nepovredivost doma, slobodu mišljenja i izražavanja misli, slobodu vjeroispovijedi itd. Na ovaj se odjeljak nadovezuje odjeljak o jamstvima gospodarskih, socijalnih i kulturnih prava, među kojima su pravo vlasništva, pravo na rad, pravo na socijalnu sigurnost i socijalno osiguranje, pravo na zdravstvenu zaštitu, pravo na obrazovanje itd.

Posebno ističemo kako su temeljem Ustava svi državljani i stranci jednaki pred sudovima i drugim državnim i inim tijelima koja imaju javne ovlasti. ${ }^{27}$ Sukladno čl. 32. Ustava, svatko tko se zakonito nalazi na teritoriju Republike Hrvatske ima pravo slobodno se kretati i birati boravište, a pravo kretanja na teritoriju Republike Hrvatske, pravo ulaska u nju i izlaska iz nje može se iznimno ograničiti zakonom ukoliko je to nužno radi zaštite pravnog poretka, ili zdravlja, te prava i sloboda drugih. Stranim državljanima i osobama bez državljanstva jamči se također pravo utočišta u Republici Hrvatskoj, osim ako su progonjeni za nepolitičke zločine i djelatnosti suprotne temeljnim načelima međunarodnog prava. Ukoliko se stranac zakonito nalazi na teritoriju Republike Hrvatske, ne može biti protjeran ili izručen drugoj državi, osim kada se mora izvršiti odluka donesena u skladu s međunarodnim ugovorom ili zakonom. ${ }^{28}$

Konačno, bitno je istaknuti kako su čl. 3. Ustava Republike Hrvatske u popis najviših vrednota ustavnog poretka i temelja za tumačenje Ustava uvršteni i jednakost (kao jednakost svih ljudi pred zakonom) i poštovanje prava čovjeka (kao osnovica djelovanja državnih i drugih tijela, ali i odnosa među pojedincima u društvu) ${ }^{29}$

\subsection{Međunarodni okvir za integraciju migranata}

Imajući u vidu kako su, prema čl. 141. Ustava Republike Hrvatske, međunarodni ugovori koji su sklopljeni i potvrđeni u skladu s Ustavom i objavljeni, a koji su na snazi, dio unutarnjega pravnog poretka Republike Hrvatske s nadzakonskom pravnom snagom, valja istaknuti kako su međunarodni standardi koji se odnose na ljudska prava migranata i njihovu integraciju dio brojnih međunarodnih dokumenata, od Opće deklaracije o ljudskim pravima (1948.) ${ }^{30}$ preko Međunarodnog pakta o građanskim i političkim pravima (1966. $)^{31}$ i Međunarodnog pakta o gospodarskim,

27 Čl. 26. Ustava Republike Hrvatske.

28 Čl. 33. st. 2. Ustava Republike Hrvatske.

29 Smerdel, B., Sokol, S., Ustavno pravo, Narodne novine, Zagreb, 2009., str. 114.

30 Opća deklaracija o ljudskim pravima, Narodne novine - Međunarodni ugovori, br. 2/09.

31 Međunarodni pakt o građanskim i političkim pravima, Narodne novine - Međunarodni ugovori, br. 12/93., 7/95. i 11/95. 
socijalnim i kulturnim pravima (1966.), ${ }^{32}$ do Konvencije protiv mučenja i drugih okrutnih, neljudskih i ponižavajućih postupanja i kažnjavanja (1984. ${ }^{33}$ i Konvencije o pravima djeteta (1989.). ${ }^{34}$ Naravno, ovi su dokumenti dopunjeni europskim regionalnim okvirom, pri čemu ističemo Konvenciju Vijeća Europe za zaštitu ljudskih prava i temeljnih sloboda (1950.) ${ }^{35}$ i Europsku konvenciju za sprečavanje mučenja i neljudskog ili ponižavajućeg postupanja ili kažnjavanja (1987.), ${ }^{36} \mathrm{~s}$ pripadajućim protokolima.

Središnje mjesto u međunarodnoj zaštiti izbjeglica općenito ima Konvencija o statusu izbjeglica (1951.) s pripadajućim protokolom $\left(1967 .{ }^{37}\right),{ }^{38}$ koja objedinjuje međunarodne dokumente iz prethodnog razdoblja koji se odnose na izbjeglice, odnosno predstavlja kodifikaciju prava izbjeglica na međunarodnoj razini. Konvencija se temelji na čl. 14. Opće deklaracije o ljudskim pravima, prema kojemu svatko pred progonom ima pravo tražiti i dobiti utočište (azil) u drugim zemljama. Osim što pruža (već spomenutu) jedinstvenu definiciju pojma izbjeglice, kao osobe koja se zbog osnovanog straha od proganjanja radi svoje rase, vjere, nacionalnosti, pripadnosti određenoj društvenoj skupini ili političkog mišljenja, ne može ili ne želi vratiti u svoju državu podrijetla (čl. 1.), ${ }^{39}$ važnost Konvencije ogleda se i u tome što se ona zasniva na temeljnim načelima zabrane diskriminacije, kažnjavanja i protjerivanja, te utvrđuje minimalne standarde postupanja s izbjeglicama. Tako se, sukladno čl. 3. Konvencije, odredbe Konvencije primjenjuju bez diskriminacije s obzirom na rasu, vjeru ili državu podrijetla. Nadalje, Konvencija utvrđuje da izbjeglice ne smiju, uz posebne iznimke, biti kažnjeni za nezakonit ulazak ili boravak u zemlji. Naime, sukladno čl. 31. Konvencije, zabranjeno je izreći kazne zbog nezakonitoga ulaska ili boravka u zemlji izbjeglicama koji su došli izravno s

32 Međunarodni pakt o gospodarskim socijalnim i kulturnim pravima, Narodne novine-Međunarodni ugovori, br. 12/93.

33 Konvencija protiv mučenja i drugih okrutnih, neljudskih i ponižavajućih postupanja i kažnjavanja, Narodne novine - Međunarodni ugovori, br. 12/93., 2/05., 3/07.

34 Konvencija o pravima djeteta, Narodne novine - Međunarodni ugovori, br. 12/93.

35 Konvencija Vijeća Europe za zaštitu ljudskih prava i temeljnih sloboda, Narodne novine Međunarodni ugovori, br. 18/97., 6/99. - pročišćeni tekst, 8/99. - ispravak, 14/02., 13/03., 9/05., 1/06., $2 / 10$.

36 Europska konvencija za sprečavanje mučenja i neljudskog ili ponižavajućeg postupanja ili kažnjavanja, Narodne novine - Međunarodni ugovori, br. 14/97.

37 Protokolom iz 1967. uklonjeno je vremensko i zemljopisno ograničenje Konvencije iz 1951. godine.

38 Konvencija o statusu izbjeglica i pripadajući protokol, Narodne novine - Međunarodni ugovori, br. $12 / 93$.

39 Ipak, valja istaknuti kako se Konvencija ne primjenjuje na sve osobe koje bi inače mogle zadovoljiti uvjete navedene u čl. 1. Tako se Konvencija ne primjenjuje na osobu za koju postoje ozbiljni razlozi za sumnju: a) da je počinila zločin protiv mira, ratni zločin, ili zločin protiv čovječnosti propisan međunarodnim pravom; b) da je počinila ozbiljan nepolitički zločin izvan zemlje utočišta prije nego što je u nju prihvaćena kao izbjeglica, te c) da je kriva za postupke koji su u suprotnosti s ciljevima i načelima Ujedinjenih naroda (čl. 1. F). Konvencija se također ne primjenjuje na osobe koje trenutno primaju pomoć ili zaštitu tijela ili agencija Ujedinjenih naroda, osim Visokog povjerenika Ujedinjenih naroda za izbjeglice (čl. 1. D). Također, Konvencija se ne primjenjuje ni na one izbjeglice kojima su nadležna tijela zemlje u kojoj imaju boravište priznala prava i obveze koje proizlaze iz posjedovanja državljanstva te zemlje (čl. 1. E). 
područja gdje je ugrožen njihov život ili sloboda, a ušli su ili se nalaze na području zemlje bez dozvole i pri tome su se bez odgode javili vlastima, te predočili valjane razloge nezakonitog ulaska ili boravka u zemlji. Također je važno istaknuti kako Konvencija predviđa mehanizme protiv prisilnog udaljenja ili vraćanja. Naime, prema čl. 32. Konvencije, država ne smije udaljiti izbjeglicu koji zakonito boravi na njezinu teritoriju, osim u slučaju ugroze nacionalne sigurnosti ili javnog reda. Nadalje, prisilno udaljenje može se provesti samo nakon odluke koja je sukladna zakonu, ${ }^{40}$ a država je dužna dati odgovarajući razuman rok izbjeglici kako bi mogao zatražiti dozvolu za ulazak u drugu zemlju. Načelo zabrane prisilnog vraćanja ("nonrefoulement") ugrađeno je u čl. 33. Konvencije, prema kojemu nijedna država ni na koji način ne smije protjerati niti vratiti izbjeglicu na područje gdje bi njegov život ili sloboda bili ugroženi zbog njegove rasne, vjerske ili nacionalne pripadnosti, ili zbog pripadnosti određenoj društvenoj skupini, ili zbog političkog mišljenja. ${ }^{41}$

Konačno, Konvencija utvrđuje temeljne standarde postupanja s izbjeglicama, te jamči set prava koja uključuju pravo na pristup sudovima (čl. 16.), pravo na obrazovanje (čl. 22.), pravo na plaćeno zaposlenje (čl. 17.), pravo na stanovanje (čl. 21.), pravo na socijalno osiguranje (čl. 24.) itd. Posebno valja izdvojiti čl. 34. Konvencije, prema kojemu su države dužne u najvećoj mogućoj mjeri omogućiti asimilaciju i prirođenje izbjeglica.

\subsection{Okvir Europske unije za integraciju migranata}

Povelja Europske unije o temeljnim pravima ${ }^{42}$ sadrži cijeli niz ljudskih prava i sloboda, poput zabrane diskriminacije po bilo kojoj osnovi, zabrane mučenja i nečovječnog postupanja i kažnjavanja, prava na obrazovanje, prava na rad, prava na azil itd. Upravo je ova Povelja temelj na kojemu je izgrađena europska integracijska politika. U osnivačkim ugovorima Europske unije integracija migranata se ne spominje, a jedino Amsterdamski ugovor (1997.) sadrži dvije odredbe koje se implicitno odnose na integraciju. ${ }^{43}$ Prvi osnivački ugovor koji eksplicitno spominje

40 Prema čl. 32. st. 2. Konvencije, osim u slučaju postojanja valjanih razloga vezano uz zaštitu nacionalne sigurnosti, izbjeglici će biti dopušteno predočiti dokaze u cilju dokazivanja svoje nedužnosti, te će se moći žaliti i u vezi sa svojim slučajem biti zastupan pred nadležnim tijelima vlasti.

${ }^{41}$ Ipak, sukladno čl. 33. st. 2. Konvencije, olakšicu koju pruža navedena odredba ne može koristiti izbjeglica kojega se opravdano smatra opasnim za sigurnost zemlje u kojoj se nalazi ili koji, nakon što je pravomoćno osuđen za posebno težak zločin, predstavlja opasnost za društvo te zemlje.

42 Povelja Europske unije o temeljnim pravima, Službeni list Europske unije, C 202/390, 2016., dostupno na: https://eur-lex.europa.eu/legal-content/HR/TXT/PDF/?uri=CELEX:12016P/TXT\&from $=\mathrm{EN}$, pristupljeno: 15 . rujna 2019 .

43 Riječ je o čl. 73k, u kojemu se navodi obveza Vijeća da u roku od pet godina usvoji mjere integracijske politike, među kojima se ističu uvjeti ulaska i boravka migranata i standardne procedure koje države članice trebaju promatrati u vezi s viznim režimom, boravišnim dozvolama i spajanjem obitelji. Treaty of Amsterdam amending the Treaty on European Union, the Treaties establishing the European Communities and certain related act, dostupno na: https://eur-lex.europa.eu/legal-content/HR/ TXT/?uri=CELEX:11997D/TXT 
integraciju jest Lisabonski ugovor (2007.). ${ }^{44}$ Naime, u čl. 79. st. 4. Lisabonskog ugovora navodi se kako Europski parlament i Vijeće, odlučujući u skladu s redovnim zakonodavnim postupkom, mogu utvrditi mjere kojima se potiče i podupire djelovanje država članica s ciljem promicanja integracije državljana trećih zemalja koji zakonito borave na njihovu području, pri čemu je isključeno bilo kakvo usklađivanje propisa država članica.

Za razliku od migracijske politike, koja spada pod tzv. prvi stup, integracijske politike potpadaju pod tzv. treći stup, odnosno nisu obvezujuće za države članice. ${ }^{45}$ Međutim, iako su europske integracijske politike u nadležnosti država članica, Europska je unija razvila zajednički okvir za integraciju državljana trećih država. Iako su pojedini aspekti integracije naglašeni još u nekim starijim dokumentima, ${ }^{46}$ potreba zajedničkog pristupa integraciji državljana trećih zemalja postaje naglašenija donošenjem zaključaka sa sastanka Europskog vijeća u Tampereu (1999.), ${ }^{47}$ u skladu s kojima je Europska komisija usvojila Priopćenje o imigracijskoj politici (2000.), ${ }^{48}$ u kojemu su izloženi daljnji ciljevi i planovi razvoja integracijske politike. U tom se dokumentima naglašava kako su migracije multidimenzionalni fenomen koji ima pravne, društvene i političke učinke, te kako razvijanje zajedničke politike stoga implicira definiranje odgovarajuće politike. Unutar tog okvira Europska komisija zagovara tzv. horizontalni pristup integraciji, koji uključuje partnerski odnos državne, regionalne i lokalne vlasti, te civilnog društva u cilju maksimalizacije pozitivnih učinaka integracije. Također, ovim se dokumentom naglašava kako proaktivna migracijska politika podrazumijeva, inter alia, i borbu protiv diskriminacije, ksenofobije i rasizma, borbu protiv ilegalnih migracija, trgovanja i krijumčarenja ljudima, te partnerstvo s državom podrijetla migranata.

44 Pročišćene inačice Ugovora o Europskoj uniji i Ugovora o funkcioniranju Europske unije, 2010/C 83/01, dostupno na: http://www.mvep.hr/custompages/static/hrv/files/pregovori/111221-lisabonskiprociscena.pdf, pristupljeno: 15. rujna 2019.

45 Božić, S., Kuti, S., „Europska politika integracije migranata: od standardiziranja mjera za zemlje Europske unije prema integracijskom servisu utemeljenom na društvenoznanstvenim spoznajama“, Revija za sociologiju, 48, 2018., 1, str. 51.

46 Tu prije svega mislimo na Europsku socijalnu povelju iz 1961., kojom je zajamčeno pravo na spajanje obitelji radnika migranata, te Akcijski program Europske komisije u korist migrantskih radnika i njihovih obitelji iz 1974., u kojemu se naglašava potreba ulaganja većih napora u sljedećim područjima važnima za migrantske radnike i njihove obitelji: radni i životni uvjeti, sloboda kretanja, socijalna sigurnost, jezični tečajevi, socijalne službe, stanovanje, obrazovanje djece, zdravlje, te se naglašava potreba koordinacije migrantskih politika. Action programme in favour of migrants workers and their families, 14 December 1974, dostupno na: http://aei.pitt.edu/1278/1/action_migrant_workers_COM_74_2250.pdf, pristupljeno: 21. rujna 2019.

47 Tampere European Council 15 and 16 October 1999, Presidencial Conclusions, dostupno na: https://www.consilium.europa.eu/media/21059/tampere-european-council-presidency-conclusions.pdf, pristupljeno: 15. rujna 2019.

48 Communication from the Commission to the Council and the European Parliament on a Community Immigration Policy, COM/2000/0757, dostupno na: https://eur-lex.europa.eu/legal-content/ EN/TXT/?uri=celex:52000DC0757. pristupljeno: 15. rujna 2019. 
Temelj za daljnji razvoj europske integracijske politike čini Priopćenje o imigraciji, integraciji i zapošljavanju (2003.) ${ }^{49}$ u kojemu su, inter alia, navedene mjere koje je potrebno poduzeti u cilju jačanja koordinacije integracijskih politika. U skladu s tim, u III. dijelu ovog dokumenta zagovara se holistički pristup integraciji koji uzima u obzir ne samo ekonomske i socijalne aspekte integracije, nego i pitanja vezana uz kulturnu i religioznu različitost, državljanstvo, participaciju i politička prava. Kao glavni elementi holističkog integracijskog procesa navedeni su: 1) integracija u tržište rada; 2) obrazovanje i jezične vještine; 3) stanovanje i urbana pitanja; 4) zdravlje i socijalne službe; 5) društveni i kulturni okoliš, te 6) nacionalnost, državljanstvo i poštovanje različitosti. Ipak, valja naglasiti kako u ovo vrijeme još uvijek integracijska politika nije bila zamišljena kao zajednička svim državama članicama.

Daljnji korak prema zajedničkoj integracijskoj politici predstavljaju Zajednička temeljna načela integracije (2004.), ${ }^{50}$ dokument čiji je cilj pomoći državama članicama u formiranju integracijskih politika. U tom kontekstu navodi se sljedećih jedanaest zajedničkih temeljenih načela integracije: 1) integracija kao dvosmjeran dinamičan proces uzajamne akomodacije migranata i stanovnika država članica; 2) poštovanje temeljnih vrijednosti Europske unije; 3) zapošljavanje kao ključni element integracijskog procesa i centralni za participaciju migranata; 4) temeljno poznavanje jezika, povijesti, kulture i institucija; 5) napori u obrazovanju kao kritično važan element pripreme migranata na participaciju u društvu; 6) pristup migranata institucijama, javnim i privatnim uslugama; 7) frekventna interakcija između migranata i građana država članica (zajednički forumi, interkulturalni dijalog, edukacija o migrantima i njihovoj kulturi, stimuliranje životnih uvjeta u urbanoj sredini); 8) sloboda vjeroispovijedi i kulture; 9) politička participacija migranata; 10) uključivanje integracijske politike i mjera u relevantna područja javnih politika, te 11) kontrola i evaluacija uspješnosti provođenja integracijske politike. Primjetno je kako je sadržajni fokus ovih jedanaest načela na migrantima kao svojevrsnim objektima integracijskog procesa, od kojih se očekuju odgovarajuća, odnosno poželjna ponašanja. Negativna karakteristika ovog dokumenta svakako je i pristup integracijskom procesu 'odozgo", a ne "odozdo", iako se deklarativno podupire participacija migranata u kreiranju integracijskih politika.

Navedena su načela dalje razvijena kroz niz praktičnih mjera sadržanih u Zajedničkom programu za integraciju državljana trećih zemalja (2005.). ${ }^{51}$ Navedeni je dokument usmjeren na usvajanje koherentnog pristupa integraciji na razini Unije,

49 Communication from the the Commission to the Council, the European Parliament, the European Economic and Social Committee and the Committee of the Regions on Immigration, Integration and Employment, COM (2003) 336, dostupno na: https://eur-lex.europa.eu/LexUriServ/LexUriServ.do?uri= COM:2003:0336:FIN:EN:PDF, pristupljeno: 15. rujna 2019.

50 The Common Basic Principles for Immigrant Integration Policy in the European Union (2004), dostupno na: https://www.eesc.europa.eu/resources/docs/common-basic-principles_en.pdf, pristupljeno: 15. rujna 2019.

51 A Common Agenda for an Integration Framework for the Integration of Third-Country Nationals in the European Union (2005), dostupno na: https://eur-lex.europa.eu/LexUriServ/LexUriServ.do?uri=C OM:2005:0389:FIN:EN:PDF, pristupljeno: 15. rujna 2019. 
te se u njemu posebna pozornost posvećuje 10. i 11. zajedničkom temeljnom načelu. U tom smislu, za ostvarivanje 10. načela (uključivanje integracijske politike i mjera u relevantna područja javnih politika), predlažu se mjere na razini država članica (primjerice, jačanje kapaciteta koordinacije nacionalne integracijske strategije na različitim razinama vlasti, poklanjanje dužne pažnje rodnoj jednakosti i specifičnim potrebama mladima i djeci migrantima) i na razini Europske unije (primjerice, razvijanje suradnje između institucija i službi odgovornih za integraciju, ugradnja integracijskih ciljeva u relevantne europske programe). Također, i za ostvarivanje 11. načela (kontrola i evaluacija uspješnosti provođenja integracijske politike) također se navode mjere na razini država članica (primjerice, jačanje kapaciteta za nadzor i evaluaciju integracijskih politika, jačanje kapaciteta za prikupljanje, analizu i diseminaciju statističkih podataka vezanih uz integraciju), te mjere na razini Europske unije (primjerice, razvoj statističkih alata i zajedničkih indikatora). Kao konkretne praktične mjere za integraciju navode se nacionalna kontakt-točka za integraciju, priručnik o integraciji, izrada web-stranice o integraciji, uspostavljanje Europskog integracijskog foruma, te godišnje izvješće Komisije o migraciji i integraciji. Ipak, i u ovom je dokumentu i dalje prisutan odnos prema migrantima kao objektima integracijskog procesa.

Nadalje, u Stockholmskom programu (2009. - 2014.) (2 $^{52}$ priznaje se kako povećana mobilnost osoba može imati pozitivne učinke na sve dionike procesa i kako je potrebno uložiti ozbiljne napore na izgradnji i jačanju dijaloga i partnerstva između Europske unije i trećih država, regija i organizacija. Također, naglašava se potreba harmonizacije integracijske politike s drugim relevantnim područjima, kao što su zapošljavanje, obrazovanje i socijalna uključenost migranata.

Uslijedio je novi val usvajanja dokumenata u području integracije, među kojima se ističe već spomenuti Europski program za integraciju državljana trećih zemalja (2011.), ${ }^{53}$ koji integraciju shvaća kao način realizacije potencijala migracije. Ovim se dokumentom konačno zagovara pristup integraciji „odozdo“, te se u tom kontekstu predlažu mjere za integraciju fokusirane u tri glavna područja: 1) integracija kroz participaciju (s aktivnostima: društveno-ekonomski doprinos migranata na području participacije na tržištu rada, napori u obrazovnom sustavu, osiguranje boljih životnih uvjeta, boljeg korištenja europskih fondova, te poštovanje općih vrednota i temeljnih ljudskih prava); 2) više aktivnosti na lokalnoj razini (s aktivnostima: adresiranje nepovoljnog položaja urbanih područja, poboljšavanje višerazinske suradnje, financijska podrška Unije lokalnim aktivnostima), te 3) uključivanje države podrijetla.

Iako je problematika integracije migranata bila djelomično obuhvaćena (i) s nekoliko dokumenata usvojenih u razdoblju između 2011. i 2016. godine, pri čemu posebno izdvajamo Priopćenje Europske komisije Put k ostvarenju otvorene i sigurne

52 The Stockholm Programme - An Open and Secure Europe Serving and Protecting Citizens, 2010/C 115/01, dostupno na: https://eur-lex.europa.eu/LexUriServ/LexUriServ.do?uri=OJ:C:2010:115:0 001:0038:EN:PDF, pristupljeno: 15. rujna 2019.

53 Vidi bilj. 13. 
Izv. prof. dr. sc. Anita Blagojević: Pravni i institucionalni okvir integracije migranata u hrvatsko društvo Zbornik radova Pravnog fakulteta u Splitu, god. 57, 3/2020, str. 707-737

Europe iz 2014. ${ }^{54}$ i Europski migracijski program iz 2015., ${ }^{55}$ jedan od važnijih i relativno recentnijih dokumenata jest Akcijski plan za integraciju državljana trećih zemalja (2016.), ${ }^{56}$ koji predstavlja zajednički okvir za podršku naporima država članica na području integracijskih politika. U cilju stvaranja „kohezivnog društva“, ovaj dokument usvojen za dvogodišnje razdoblje kao prioritetne mjere za povećanje uspješnosti integracijske politike izdvaja: mjere prije odlaska i prije dolaska, obrazovanje, integraciju u tržište rada, pristup temeljnim uslugama, kao što su smještaj i zdravstvena zaštita, te aktivna participacija i socijalna uključenost, odnosno sudjelovanje u kreiranju i implementaciji integracijskih politika.

Konačno, iako je područje integracije prepušteno državama članicama Europske unije, na razini Unije doneseno je nekoliko direktiva vezano uz integraciju, koje je u svoje nacionalno zakonodavstvo prenijela i Republika Hrvatska. ${ }^{57}$

\subsection{Zakonski okvir za integraciju migranata}

\section{Već spomenuta harmonizacija hrvatskog zakonodavstva s acquis} communaitaireom Europske unije imala je neupitan značaj za razvoj hrvatske integracijske politike. Rezultat su tog procesa novousvojeni ili izmijenjeni i

54 Iako je u ovom dokumentu naglasak ponajprije na sigurnosnim pitanjima i rizicima, naglašava se i područje migracija i integracije migranata. U tom kontekstu se u točki 1.1. navodi kako je Europa raznoliko društvo u kojemu integracija predstavlja izazov, te kako za postizanje veće društvene kohezije i ostvarivanja veće koristi od migracija treba raditi na jačanju učinkovite integracije migranata na tržištu rada. Posebno se naglašava kako se jači napori trebaju uložiti vezano uz položaj žena, mladih migranata i djece bez pratnje. Communication from the Commission to the European Parliament, the Council, the European Economic and Social Committee and the Committee of the Regions: An open and secure Europe: making it happen, dostupno na: https://ec.europa.eu/home-affairs/sites/homeaffairs/files/elibrary/documents/basic-documents/docs/an_open_and_secure_europe_-_making_it_happen_en.pdf, pristupljeno: 21. rujna 2019.

55 U ovom dokumentu naglasak je na mjerama za upravljanje i suzbijanje neregularnih migracija. Ipak, jedan dio točke III. 4 odnosi se na učinkovitu integraciju. U tom kontekstu, navodi se kako će migracijska politika uspjeti jedino potpomognuta učinkovitim integracijskim politikama. Iako nadležnost za ovo područje pripada državama članicama, naglašava se kako Unija može dati svoj doprinos aktivnostima državnih i lokalnih vlasti, te civilnog društva u cilju uspješne integracije migranata. Također se navodi kako je financiranje omogućeno od strane Fonda za azil, migraciju i integraciju (Asylum Migration and Integration Fund-AMIF). Communication from the Commission to the European Parliament, the Council, the European Economic and Social Committee and the Committee of the Regions: a European Agenda on Migration, dostupno na: https://ec.europa.eu/anti-trafficking/sites/antitrafficking/files/communication_ on_the_european_agenda_on_migration_en.pdf, pristupljeno: 21. rujna 2019.

56 Action Plan on the Integration of Third-country Nationals, COM(2016) 377, dostupno na: https:// ec.europa.eu/home-affairs/sites/homeaffairs/files/what-we-do/policies/european-agenda-migration/ proposal-implementation-package/docs/20160607/communication_action_plan_integration, pristupljeno: 15. rujna 2019.

57 Riječ je o sljedećim direktivama: Direktiva Vijeća 2003/109/EZ od 25. studenog 2003. o statusu državljana trećih država koji imaju stalni boravak; Direktiva Vijeća 2003/86/EZ od 22. rujna 2003. o pravu na spajanje obitelji; Direktiva Vijeća 2004/114/EZ od 13. prosinca 2004. o uvjetima prihvata državljana trećih država u svrhu studiranja, razmjene učenika, neplaćene izobrazbe i dobrovoljnog rada; Direktiva Vijeća 2005/71/EZ od 12. listopada 2005. o posebnom postupku za ulazak državljana trećih država u svrhu znanstvenog istraživanja; Direktiva Vijeća 2009/50/EZ od 25. svibnja 2009. o uvjetima za ulazak i boravak državljana trećih država u svrhu zapošljavanja visokokvalificiranih osoba; Direktiva Europskog parlamenta i Vijeća 2011/98/EU od 13. prosinca 2011. o jednom postupku prijave za jednu dozvolu za državljane trećih zemalja da žive i radu na području države članice. 
dopunjeni propisi, tako da danas hrvatski zakonski okvir za integraciju migranata čini nekoliko zakona i niz podzakonskih propisa. Tako, primjerice, Zakon o strancima ${ }^{58}$ propisuje uvjete ulaska, kretanja, boravka i rada državljana trećih zemalja i državljana država članica europskog gospodarskog prostora i članova njihovih obitelji, te uvjete rada i prava upućenih radnika u Republiku Hrvatsku, dok Zakon o hrvatskom državljanstvu ${ }^{59}$ uređuje hrvatsko državljanstvo, odnosno pretpostavke za njegovo stjecanje i prestanak.

Krovni zakon za integraciju migranata jest Zakon o međunarodnoj i privremenoj zaštiti, ${ }^{60}$ koji je zamijenio do 1 . srpnja 2015. važeći Zakon o azilu. Ovim se Zakonom uređuju načela, uvjeti i postupak odobrenja međunarodne i privremene zaštite, status, prava i obveze tražitelja međunarodne zaštite, azilanata, stranaca pod supsidijarnom i privremenom zaštitom, te uvjeti i postupak poništenja i prestanak azila, te supsidijarne privremene zaštite. Navedenim su Zakonom, dakle, regulirana prava i obveze tri kategorije osoba: 1) tražitelja međunarodne zaštite (koji je definiran u čl. 4. Zakona kao državljanin treće zemlje ili osoba bez državljanstva koja izrazi namjeru za podnošenje zahtjeva za međunarodnu zaštitu do izvršnosti odluke o zahtjevu, a iznimno i državljanina države članice Europske unije kada je to propisano Protokolom 24. Lisabonskog ugovora); 2) azilanta i stranca pod supsidijarnom zaštitom (s tim da je azilant $u$ čl. 4. Zakona definiran kao izbjeglica $u$ smislu Konvencije o statusu izbjeglica iz 1951., kojoj je priznat azil, dok je stranac pod supsidijarnom zaštitom definiran kao državljanin treće zemlje ili osoba bez državljanstva kojoj je priznata supsidijarna zaštita), te 3) stranca pod privremenom zaštitom (koji je u čl. 4. Zakona definiran kao državljanin treće zemlje ili osoba bez državljanstva kojemu je odobrena privremena zaštita). ${ }^{61}$

U čl. 52. Zakona navedeno je koja prava (i obveze) ${ }^{62}$ imaju tražitelji međunarodne zaštite: a) pravo na boravak (sukladno čl. 53. Zakona, tražitelj ima pravo na boravak u Republici Hrvatskoj od dana izražene namjere do izvršnosti odluke o zahtjevu); b) slobodu kretanja (s tim da se, sukladno čl. 54. st. 2. Zakona, tražitelju može ograničiti sloboda kretanja ako se na temelju svih činjenica i okolnosti konkretnog slučaja procijeni da je to potrebno radi: utvrđivanja činjenica i okolnosti na kojima se temelji zahtjev za međunarodnu zaštitu, a koje se ne mogu utvrditi bez ograničenja slobode kretanja, osobito ako se ocijeni da postoji rizik od bijega, zatim radi utvrđivanja i provjere identiteta ili državljanstva, radi zaštite nacionalne sigurnosti ili javnog poretka Republike Hrvatske, te radi sprečavanja zloupotrebe postupka ako se na temelju objektivnih kriterija osnovano sumnja da je namjera izražena

58 Zakon o strancima, Narodne novine, br. 130/11., 74/13., 69/17., 46/18.

59 Zakon o hrvatskom državljanstvu, Narodne novine, br. 53/91., 70/91., 28/92., 113/93., 4/94., 130/11., 110/15.

60 Zakon o međunarodnoj i privremenoj zaštiti, Narodne novine, br. 70/15., 127/17.

${ }^{61}$ Privremena zaštita u smislu čl. 4. st. 4. Zakona podrazumijeva zaštitu hitnog i privremenog karaktera koja se uvodi na temelju odluke Vijeća Europske unije o postojanju masovnog priljeva raseljenih osoba.

62 Sukladno čl. 52. st.3. Zakona, tražitelji zaštite dužni su poštovati Ustav, zakone i druge pravne propise Republike Hrvatske, surađivati s državnim tijelima, podvrgnuti se provjeri i utvrđivanju identiteta, podvrgnuti se zdravstvenom pregledu, poštovati Kućni red prihvatilišta, pojaviti se u prihvatilištu u roku koji mu je određen itd. 
tijekom postupka prisilnog udaljenja radi onemogućavanja daljnjeg postupanja), ${ }^{63}$ c) osiguranje odgovarajućih materijalnih uvjeta prihvata (što podrazumijeva, prema čl. 55. Zakona, smještaj u prihvatilištu, hranu i odjeću osiguranu u naravi, naknadu troškova javnog prijevoza za potrebe postupka odobrenja međunarodne zaštite, te novčanu pomoć); ${ }^{64} \mathrm{~d}$ ) pravo na zdravstvenu zaštitu (koja obuhvaća hitno medicinski i prijeko potrebno liječenje bolesti i ozbiljnih mentalnih poremećaja); e) pravo na osnovno i srednje obrazovanje (koje dijete tražitelj ostvaruje pod istim uvjetima kao i hrvatski državljanin, s tim da, sukladno čl. 58. st. 4. Zakona, ako dijete tražitelj ne zna ili nedovoljno poznaje hrvatski jezik, treba mu se omogućiti pohađanje pripremne nastave ili dopunske nastave hrvatskog jezika, kao i dopunske nastave u pojedinim nastavnim predmetima, ako za to postoji potreba); f) pravo na informacije (koje podrazumijeva, prema čl. 59. Zakona, da su državljaninu treće zemlje ili osobi bez državljanstva na graničnom prijelazu, ili u prihvatnom centru, ili u tranzitnom prostoru zračne, morske luke ili luke unutarnjih voda, koja bi željela izraziti namjeru, policijski službenici dužni pružiti sve potrebne informacije o postupku odobrenja međunarodne zaštite na jeziku za koji se opravdano pretpostavlja da ga razumije i na kojemu može komunicirati); ${ }^{65} \mathrm{~g}$ ) pravo na pravno savjetovanje (koje podrazumijeva, sukladno čl. 59. st. 3. i 4. Zakona, da će se tražitelju na njegov zahtjev pružiti pravne i postupovne informacije o odobrenju međunarodne pomoći, uzimajući u obzir okolnosti konkretnog slučaja, na jeziku koji razumije, s tim da ovo pravno savjetovanje pružaju organizacije koje se bave zaštitom prava izbjeglica ili odvjetnici s kojima Ministarstvo sklopi ugovor o provođenju pravnog zastupanja); h) pravo na besplatnu pravnu pomoć (koje se ostvaruje na temelju zahtjeva tražitelja ili stranca koji ne posjeduju dovoljno novčanih sredstava ili stvari veće vrijednosti, $\mathrm{s}$ tim da, prema čl. 60. st. 2. Zakona, ova pravna pomoć obuhvaća pomoć u sastavljanju tužbe, zastupanje u prvostupanjskom upravnom sporu i oslobođenje od plaćanja troškova prvostupanjskog upravnog spora); ${ }^{66}$ i) slobodu vjeroispovijedi; j) pravo na rad (s tim da tražitelj, temeljem čl. 61. Zakona, stječe pravo na rad istekom roka od devet mjeseci od dana podnošenja zahtjeva o kojemu Ministarstvo nije donijelo odluku, pod uvjetom da tražitelj nije svojim ponašanjem utjecao na razloge nedonošenja odluke), te k) pravo na isprave (koje podrazumijeva, prema čl. 52. Zakona, da je Ministarstvo dužno tražitelju izdati iskaznicu tražitelja međunarodne zaštite u roku od tri dana od dana podnošenja zahtjeva).

63 Sloboda kretanja tražitelja ili stranca u transferu može se ograničiti, sukladno čl. 54. st. 5. Zakona, sljedećim mjerama: zabranom kretanja izvan prihvatilišta; zabranom kretanja izvan određenog područja; osobnim pristupanjem u prihvatilište u određeno vrijeme; davanjem u polog putnih isprava i karata prihvatilištu, te smještajem u prihvatni centar za strance.

64 Navedeni materijalni uvjeti mogu se ograničiti ili uskratiti sukladno čl. 55. st. 5. Zakona, ako tražitelj: ne boravi u prihvatilištu u kojemu mu je određen smještaj; izbiva izvan prihvatilišta protivno zakonskim uvjetima (dulje od 24 sata bez prethodnog odobrenja prihvatilišta; posjeduje sredstva koja mu omogućavaju odgovarajući životni standard, te krši odredbe Kućnog reda prihvatilišta.

65 U roku od 15 dana od izražene namjere Ministarstvo je u obvezi, temeljem čl. 59. st. 2. Zakona, obavijestiti tražitelja o načinu provođenja postupka odobrenja međunarodne zaštite, kao i o pravima $\mathrm{i}$ obvezama koje ima u tom postupku i o mogućnostima obraćanja predstavnicima UNHCR-a i drugim organizacijama koje se bave zaštitom prava izbjeglica, te o mogućnosti dobivanja besplatne pravne pomoći.

${ }^{66}$ O pravu na besplatnu pravnu pomoć i o visini troškova te pomoći odlučuje upravni sud. Pružatelji pravne pomoći su odvjetnici i pravnici iz udruga registriranih za pružanje pravne pomoći. 
Što se tiče prava (i obveza) ${ }^{67}$ azilanta i stranca pod supsidijarnom zaštitom, koji svoj status stječu danom uručenja odluke o odobrenju međunarodne zaštite, isti su navedeni u čl. 64. Zakona i obuhvaćaju: a) pravo na boravak u Republici Hrvatskoj (koje se utvrđuje odlukom o odobrenju međunarodne zaštite); b) pravo na spajanje obitelji; c) pravo na smještaj (pod uvjetom da nemaju novčana sredstva ili imovinu kojima sebi mogu osigurati uzdržavanje, s tim da navedeno pravo, sukladno čl. 67. st. 4. Zakona, može trajati najdulje dvije godine od dana uručenja odluke o odobrenju međunarodne zaštite) ${ }^{68} \mathrm{~d}$ ) pravo na rad (koje podrazumijeva i pravo na obrazovanje odraslih vezano uz zaposlenje, stručno usavršavanje i stjecanje praktičnog iskustva pod istim uvjetima kao i hrvatski državljani, sukladno čl. 68. st. 2. Zakona); e) pravo na zdravstvenu zaštitu (sukladno propisu kojim se uređuje zdravstveno osiguranje i zdravstvena zaštita u Republici Hrvatskoj); f) pravo na obrazovanje (koje, temeljem čl. 70. st. 1. Zakona, uključuje pravo na osnovno, srednje i visoko obrazovanje pod istim uvjetima kao i hrvatski državljani); g) slobodu vjeroispovijedi (koja podrazumijeva, prema čl. 71. Zakona, jamstvo slobode življenja i odgoja djece u skladu s vjerskim uvjerenjima; i) pravo na besplatnu pravnu pomoć; j) pravo na socijalnu skrb (sukladno propisima kojima se uređuje područje socijalne skrbi u Republici Hrvatskoj); k) pravo na pomoć pri integraciji u društvo; l) pravo na vlasništvo nekretnine sukladno Konvenciji iz 1951., te m) pravo na stjecanje hrvatskog državljanstva sukladno propisima koji reguliraju stjecanje državljanstva.

Iz seta nabrojanih i zajamčenih prava posebno izdvajamo pravo na pomoć pri integraciji u društvo. Naime, ovo je pravo regulirano čl. 76. Zakona i ono podrazumijeva da azilant i stranac pod supsidijarnom zaštitom imaju pravo na pomoć pri uključivanju u društvo u maksimalnom trajanju od tri godine od uručenja odluke, s tim da pomoć pri uključivanju u društvo obuhvaća sljedeća tri područja: 1) izradu plana integracije s obzirom na individualne potrebe, znanja, sposobnosti i vještine azilanta i stranca pod supsidijarnom zaštitom; 2) pružanje pomoći u cilju ostvarivanja izrađenog plana, te 3) nadzor nad izvršenjem plana.

Konačno, Zakonom su regulirana i prava (i obveze) ${ }^{69}$ stranca pod privremenom zaštitom. Sukladno čl. 83. Zakona, stranac pod privremenom zaštitom ima sljedeća prava: a) pravo na boravak (za vrijeme trajanja privremene zaštite); b) pravo na iskaznicu (koja se, temeljem čl. 85. Zakona, izdaje na vrijeme od godinu dana, ali se može produljivati); c) pravo na osnovna sredstva za život i smještaj; d) pravo na zdravstvenu zaštitu (koje uključuje hitnu medicinsku pomoć, a za ranjive skupine odgovarajuću medicinsku i drugu pomoć, sukladno čl. 87. Zakona); e) pravo na osnovno i srednje obrazovanje (pod istim uvjetima kao hrvatski državljani); f) pravo na informacije o pravima i obvezama (koje podrazumijeva, prema čl. 91. Zakona,

67 Prema čl. 64. st. 4. Zakona, azilant i stranac pod supsidijarnom zaštitom dužni su: poštovati Ustav, zakone i druge propise Republike Hrvatske; prijaviti prebivalište u roku od 15 dana od uručenja odluke o odobrenju međunarodne zaštite; imati kod sebe dozvolu boravka i dati je na uvid ovlaštenim osobama, te pohađati tečaj hrvatskog jezika, povijesti i kulture.

68 Sukladno čl. 67. st. 2. i 3. Zakona, postupak za priznavanje prava na smještaj pokreće se podnošenjem zahtjeva nadležnom centru za socijalnu skrb. Centar odlučuje o zahtjevu rješenja, protiv kojega se može izjaviti žalba u roku od 15 dana od dana dostave rješenja. O žalbi odlučuje Ministarstvo nadležno za poslove socijalne skrbi.

69 Obveze koje imaju tražitelji međunarodne zaštite na odgovarajući se način primjenjuju i na strance pod privremenom zaštitom. 
obvezu Ministarstva da pisanim putem, u što kraćem roku, obavijesti stranca pod privremenom zaštitom o njegovim pravima i obvezama na jeziku za koji se opravdano pretpostavlja da ga razumije i na kojemu može komunicirati); g) pravo na rad (koje podrazumijeva i pravo na obrazovanje odraslih vezano uz zaposlenje, stručno usavršavanje i stjecanje praktičnog iskustva pod istim uvjetima kao i hrvatski državljani, sukladno čl. 86. st. 2. Zakona); h) pravo na spajanje obitelji, te i) slobodu vjeroispovijedi.

Razrada navedenih prava predmet je normiranja niza zakona i podzakonskih propisa. Tako se, primjerice, prava iz sustava socijalne skrbi razrađuju u Zakonu o socijalnoj skrbi ${ }^{70}$ (prema kojemu azilanti i stranci pod supsidijarnom zaštitom ostvaruju sva prava u sustavu socijalne skrbi u jednakom opsegu kao i hrvatski državljani s prebivalištem u Republici Hrvatskoj), ${ }^{71}$ Zakonu o doplatku za djecu ${ }^{72}$ i Zakonu o rodiljnim i roditeljskim potporama, ${ }^{73}$ dok se pravo na obrazovanje razrađuje u Zakonu o odgoju i obrazovanju u osnovnoj i srednjoj školi ${ }^{74}$ (prema kojemu tražitelji azila i stranci pod zaštitom imaju pravo na osnovno i srednje obrazovanje).

Što se tiče provedbenih dokumenata, valja istaknuti kako je u svrhu reguliranja migracijskih kretanja u Hrvatskoj i u okviru procesa pridruživanja Europskoj uniji usvojena Migracijska politika Republike Hrvatske za razdoblje od 2013. do 2015. godine ${ }^{75}$ čiji sastavni dio čini integracija stranaca u hrvatsko društvo, definirana kao „dinamičan, dvosmjeran proces međusobne prilagodbe kako stranaca, tako i hrvatskih državljana“. Ovaj dokument navodi set mjera za uklanjanje prepreka kod ostvarivanja prava u području integracije. Pet integracijskih mjera predviđenih Migracijskom politikom tako uključuju: 1) izradu prijedloga za imenovanje Stalnog povjerenstva za provedbu integracije stranaca; 2) imenovanje Radne skupine za operativnu provedbu zadaća Stalnog povjerenstva; 3) izradu akcijskog plana za uklanjanje prepreka kod ostvarivanja prava u području integracije; 4) aktivnosti koje imaju za cilj podizanje javne svijesti o različitim aspektima i uzročno-posljedičnim pojavama migracijskih kretanja, te 5) provedbu Nastavnog plana i programa hrvatskog jezika za osobe starije od 15 godina na razini svih županija.

$\mathrm{Na}$ temelju ovog dokumenta izrađen je Akcijski plan za uklanjanje prepreka u ostvarivanju pojedinih prava u području integracije stranaca za razdoblje od 2013. do 2015. godine. ${ }^{76}$

70 Zakon o socijalnoj skrbi, Narodne novine, br. 157/13., 152/14., 99/15., 52/16.

71 Čl. 22. st. 2. Zakona o socijalnoj skrbi.

72 Zakon o doplatku za djecu, Narodne novine, br. 94/01., 138/06., 107/07., 37/08., 61/11., 112/12., $82 / 15$.

73 Zakon o rodiljnim i roditeljskim potporama, Narodne novine, br. 85/08., 110/08., 34/11., 54/13., $152 / 14$.

74 Zakon o obrazovanju u osnovnoj i srednjoj školi, Narodne novine, br. 87/08., 86/09., 92/10., 105./10. - ispravak, 90/11., 16/12., 86/12., 94/13., 152/14.

75 Migracijska politika Republike Hrvatske za razdoblje od 2013. do 2015. godine, Narodne novine, br. $27 / 13$.

${ }^{76}$ Akcijski plan za uklanjanje prepreka u ostvarivanju pojedinih prava u području integracije stranaca za razdoblje od 2013. do 2015. godine, dostupno na: https://pravamanjina.gov.hr/UserDocsImages/ arhiva/30092013/Akcijski\%20plan\%20za\%20uklanjanje\%20prepreka\%20u\%20ostvarivanju\%20 pojedinih\%20prava\%20u\%20podru\%C4\%8Dju\%20integracije\%20stranaca\%20za\%20razdoblje $\% 20$ od\%202013\%20do\%202015\%20godine.pdf, pristupljeno: 20. rujna 2019. 
Nadalje, u svibnju 2017. Ured za ljudska prava i prava nacionalnih manjina Vlade Republike Hrvatske usvojio je Akcijski plan za integraciju osoba kojima je odobrena međunarodna zaštita za razdoblje od 2017. do 2019. godine,${ }^{77}$ kojim su predviđene mjere za integraciju u sljedećih sedam područja: 1) socijalna $\mathrm{skrb}^{78} \mathrm{i}$ zdravstvena zaštita; ${ }^{79}$ 2) smještaj i stanovanje; ${ }^{80} 3$ ) učenje jezika i obrazovanje; ${ }^{81}$

77 Akcijski plan za integraciju osoba kojima je odobrena međunarodna zaštita za razdoblje od 2017. do 2019. godine, dostupno na: https://pravamanjina.gov.hr/UserDocsImages/dokumenti/AKCIJSKI\%20 PLAN\%20ZA\%20INTEGRACIJU\%202017-2019.pdf, pristupljeno: 20. rujna 2019.

78 Prema Akcijskom planu, od prava iz sustava socijalne skrbi osobe kojima je odobrena međunarodna zaštita najviše koriste pravo na zajamčenu minimalnu naknadu, jednokratnu naknadu, pomoć za podmirenje troškova stanovanja, doplatak za pomoć i njegu, te pomoć za ogrjev i prehranu u pučkim kuhinjama. Akcijski plan, str. 6.

79 Za područje socijalne skrbi Akcijski plan predviđa dva cilja: 1) upoznati osobe kojima je odobrena međunarodna zaštita s pravima iz sustava socijalne skrbi, te tradicijom, kulturom i kulturnim obrascima u Republici Hrvatskoj, za što su predviđene dvije mjere (edukativna predavanja u prihvatilištu za tražitelje azila, te tematske i edukativne radionice i savjetovanja o pravima i obvezama osoba kojima je odobrena međunarodna zaštita), te 2) osiguranje ispunjavanja preduvjeta za život i suživot u lokalnim zajednicama, za što su predviđene četiri mjere (imenovanje stručnih radnika zaduženih za ostvarivanje prava osoba kojima je odobrena međunarodna zaštita, provođenje aktivnosti s ciljem podizanja kvalitete života tih osoba, dostavljanje odgovarajućih preporuka jedinicama lokalne i regionalne samouprave da u odlukama o socijalnoj skrbi obuhvate i osobe kojima je odobrena međunarodna zaštita, te dostavljanje preporuka pučkim kuhinjama da osiguraju prehranu sukladno kulturnim i vjerskim uvjerenjima stranaca). U pogledu ostvarivanja prava iz sustava zdravstvene zaštite Akcijski plan predviđa tri cilja: 1) upoznati osobe kojima je odobrena međunarodna zaštita s pravima iz sustava zdravstvene zaštite, za što su predviđene dvije mjere (informiranje osoba o relevantnom zakonodavnom okviru, te sustavno informiranje zdravstvenih radnika o okvirima prava iz relevantnog zakonodavnog okvira); 2) osigurati pristup zdravstvenoj zaštiti, za što je predviđena jedna mjera (prilagodba informacijskog sustava radi učinkovitog ostvarivanja prava na zdravstvenu zaštitu; 3) unaprijediti sustav pristupa zdravstvenoj zaštiti, za što je predviđena jedna mjera (posredovanje i pratnja osoba kojima je odobrena međunarodna zaštita pri zdravstvenim institucijama radi lakšeg razumijevanja djelokruga njihova rada i prevladavanja jezičnih i kulturoloških barijera).

${ }_{80}$ Za područje smještaja i stanovanja Akcijski plan predviđa tri cilja: 1) unaprijediti relevantnu zakonsku regulativu, za što je predviđena jedna mjera (izmjene i dopune Zakona o međunarodnoj i privremenoj zaštiti u pogledu nadležnosti Središnjeg državnog ureda za obnovu i stambeno zbrinjavanje vezano uz osiguravanje smještajnih kapaciteta); 2) unaprijediti koordinaciju nadležnih tijela u području stanovanja s ciljem žurnog ostvarivanja smještajnih kapaciteta, za što su predviđene dvije mjere (aktivna suradnja Ministarstva za demografiju, obitelj, mlade i socijalnu politiku sa Središnjim državnim uredom za obnovu i stambeno zbrinjavanje, te aktivna suradnja s Ministarstvom državne imovine), te 3) osigurati provedbu i praćenje Plana razmještaja, za što su predviđene tri mjere (objavljivanje javnih poziva za prikupljanje ponuda za najam namještenih stanova ili kuća sukladno Planu razmještaja, izrada i vođenje evidencije osoba koje koriste pravo na smještaj, te zapošljavanje optimalnog broja osoba u Središnjem državnom uredu).

${ }^{81}$ Za ovo su područje Akcijskim planom predviđena tri cilja: 1) provoditi učenje hrvatskog jezika za sve dobne skupine kao prvog preduvjeta uspješne integracije, za što su predviđene dvije mjere (osiguravanje učenja hrvatskog jezika, povijesti i kulture u svim gradovima u kojima su smještene osobe kojima je odobrena međunarodna zaštita, te osiguravanje provedbe pripremne i dopunske nastave za učenike osnovnih i srednjih škola koji ne znaju ili nedostatno znaju hrvatski jezik); 2) unaprijediti pristup obrazovanju svim dobnim skupinama s ciljem nastavka obrazovanja i zaposlenja, za što je predviđeno sedam mjera (u najkraćem roku uključivanje djece u škole, omogućavanje osobama na visokim učilištima da podnesu prijavu na natječaje za državne stipendije i studentski smještaj, prilagodba informacijskog sustava za upis na visoka učilišta, osiguravanje priznavanja obrazovnih kvalifikacija i ranije stečenih kompetencija, omogućavanje osobama starijima od 15 godina završetak obrazovanja, kao i besplatnih prekvalifikacija, te informiranje odgojno-obrazovnih institucija o pravima osoba kojima je odobrena međunarodna zaštita), te 3) osnažiti kapacitete i integrativne aktivnosti u obrazovnom sustavu, za što su predviđene dvije mjere (provedba stručnog usavršavanja odgojno-obrazovnih radnika, te osnaživanje partnerstva odgojno-obrazovnih institucija i organizacija civilnog društva). 
4) zapošljavanje, ${ }^{82}$ 5) međunarodna suradnja; ${ }^{83}$ 6) međuresorna suradnja ${ }^{84}$ te 7) senzibilizacija javnosti i stručnih djelatnika o osobama kojima je odobrena međunarodna zaštita. ${ }^{85}$ Od ostalih dokumenata izdvojit ćemo još samo Nacionalni program zaštite i promicanja ljudskih prava za razdoblje od 2013. do 2016. godine, ${ }^{86}$ koji među prioritetnim područjima navodi i unapređenje integracije azilanata i stranaca pod supsidijarnom zaštitom.

82 Akcijskim planom predviđeno je pet mjera na području zapošljavanja: 1) doprinijeti lakšem ostvarivanju prava na rad, za što je predviđena jedna mjera (aktiviranje i motiviranje osoba kojima je odobrena međunarodna zaštita u program učenja hrvatskog jezika prilikom individualnih savjetovanja u Hrvatskom zavodu za zapošljavanje); 2) upoznati osobe s pravima i obvezama na području zapošljavanja, za što su predviđene dvije mjere (informiranje osoba o njihovim pravima i obvezama, te njihovo savjetovanje i profesionalno usavršavanje); 3) osnažiti kapacitete zaposlenika u sustavu zapošljavanja za rad s osobama kojima je odobrena međunarodna zaštita, za što je predviđena jedna mjera (educiranje radnika Hrvatskog zavoda za zapošljavanje); 4) provoditi mjere aktivne politike zapošljavanja osoba kojima je odobrena međunarodna zaštita, za što je previđena jedna mjera (uključivanje osoba kojima je odobrena zaštita u mjere aktivne politike zapošljavanja), te 5) unapređenje sustava pristupa zapošljavanju osoba kojima je odobrena zaštita, za što su predviđene dvije mjere (izrada profesionalnog plana traženja posla, te financiranje obrazovanja nezaposlenih osoba temeljem utvrđenih potreba za obrazovanjem).

${ }^{83}$ Na području međunarodne suradnje Akcijski plan predviđa samo jedan cilj: osigurati prijenos $i$ razmjenu iskustava u suočavanju s poteškoćama integracije osoba kojima je odobrena međunarodna zaštita među članicama Europske unije, za što su predviđene dvije mjere (suradnja i sudjelovanje na sastancima u okviru Europske integracijske mreže, te suradnja s tijelima državne uprave, organizacijama civilnog društva i međunarodnim organizacijama u regionalnim i međunarodnim projektima i inicijativama na području integracije).

${ }^{84}$ U okviru međuresorne suradnje Akcijski plan predviđa tri mjere: 1) praćenje provedbe integracije osoba kojima je odobrena međunarodna zaštita, za što je predviđeno sedam mjera (praćenje provedbe Akcijskog plana, donošenje Plana razmještaja jednom godišnje, uspostava mreže kontakt-osoba, podnošenje godišnjeg izvješća Vladi Republike Hrvatske o provedbi Akcijskog plana, uspostava online sustava za praćenje provedbe Akcijskog plana, treninzi za trenere za uporabu tog on-line sustava, te obavještavanje na mjesečnoj razini Ureda za ljudska prava i prava nacionalnih manjina Vlade Republike Hrvatske o najnovijim saznanjima o osobama kojima je odobrena zaštita); 2) unapređenje postojećih procedura postupanja i okvira integracije, za što je predviđeno pet mjera (izrada protokola o postupanju s osobama kojima je odobrena zaštita, evaluacija Akcijskog plana, izrada novog provedbenog integracijskog okvira na lokalnoj razini, izrada i tisak publikacije o evaluaciji Akcijskog plana, te izrada i tisak vizualnog identiteta Akcijskog plana), te 3) cjelovito informiranje osoba kojima je odobrena međunarodna zaštita o njihovim pravima i obvezama, za što su predviđene tri mjere (izrada, tisak i prijevod kataloga prava i obveza, izmjene i dopune te tiskanje i prijevod vodiča za integraciju, te osiguravanje usluge prevođenja osobama u ostvarivanju njihovih prava).

85 U okviru senzibilizacije javnosti i stručnih djelatnika Akcijskim planom predviđena su tri cilja: 1) senzibiliziranje javnosti i smanjivanje društvenih predrasuda, za što je predviđena jedna mjera (javna kampanja na nacionalnoj razini); 2) senzibiliziranje stručnih djelatnika, za što su predviđene četiri mjere (edukacija odgovarajućih stručnih djelatnika, edukacija stručnih radnika u sustavu socijalne skrbi, kontinuirano informiranje poslodavaca, sindikata, te djelatnika službe zapošljavanja o pravima osoba kojima je odobrena zaštita, te edukacija zdravstvenih djelatnika), te 3) podržavanje inicijative medija, civilnog društva i građana vezano uz integraciju, za što su predviđene dvije mjere (potpora odgovarajućim projektima, te potpora partnerskim programima organizacija civilnog društva u njegovanju i promicanju raznolikosti kulturnih izričaja).

86 Nacionalni program zaštite i promicanja ljudskih prava za razdoblje od 2013. do 2016. godine, dostupno na: https://pravamanjina.gov.hr/UserDocsImages/dokumenti/Nacionalni\%20program\%20za\% c5\%a1tite\%20i\%20promicanja\%20ljudskih\%20prava\%20za\%20razdoblje\%20od\%202013.\%20do\%20 2016.\%20godine.pdf, pristupljeno: 20. rujna 2019. 


\subsection{Praksa Ustavnog suda Republike Hrvatske}

Kada je riječ općenito o ustavnim pravima migranata u Hrvatskoj, krovna institucija za zaštitu njihovih Ustavom zajamčenih prava jest Ustavni sud Republike Hrvatske. Sukladno čl. 129. Ustava Republike Hrvatske, Ustavni sud, inter alia, odlučuje povodom ustavnih tužbi protiv pojedinačnih odluka državnih tijela, tijela jedinica lokalne i područne (regionalne) samouprave, te također pravnih osoba s javnim ovlastima, kada su tim odlukama povrijeđena ljudska prava i temeljne slobode, kao i pravo na lokalnu i područnu (regionalnu) samoupravu, zajamčeni Ustavom Republike Hrvatske. Izdvajamo dva recentna predmeta iz prakse Ustavnog suda.

Prvi put se Ustavni sud u svojoj praksi bavio ustavnim pravima migranata vezano uz uvjete smještaja podnositelja ustavne tužbe u jednom prihvatnom centru za strance, za vrijeme dok su čekali donošenje odluke o njihovim zahtjevima za međunarodnu zaštitu, u odluci broj: U-IIIBi-1385/2018 od 18. prosinca 2018. godine ${ }^{87}$ Ustavni sud je razmatrao dva prigovora podnositelja, migrantske obitelji iz Afganistana: 1) prigovor vezan uz istragu smrti pokojne malodobne Madine Hussainkhel (Hassinly), te 2) prigovor vezan uz uvjete smještaja podnositelja u Tranzitnom prihvatnom centru za strance u Tovarniku. Oba je prigovora Ustavni sud ocijenio neosnovanima. U pogledu prvog prigovora, Ustavni sud je nakon sagledavanja proceduralnog aspekta slučaja, odnosno saznanja dobivenih od Državnog odvjetništva i drugih nadležnih pravosudnih tijela istrage, zaključio da je provedena djelotvorna istraga smrti malodobne Madine. Ipak, valja napomenuti kako su troje sudaca Ustavnog suda ${ }^{88} \mathrm{u}$ svojem Izdvojenom mišljenju izrazili svoje „čvrsto uvjerenje da Ustav Republike Hrvatske ne dopušta da se izgubljeni život šestogodišnje djevojčice svede na proceduralni formalizam u pristupu nadležnih pravosudnih tijela istrage", odnosno u svojem su mišljenju naveli kako smatraju da u konkretnom slučaju nije provedena učinkovita istraga. U prilog takvom mišljenju navode određene nedostatke u provedbi istrage, koje je primijetila i Pučka pravobraniteljica, koja je provela samostalnu istragu povodom smrti malodobne djevojčice te uočila slične nedostatke. Nažalost, moramo se složiti s ovim izdvojenim mišljenjem, jer smo također čvrstog uvjerenja da se izgubljeni život šestogodišnje djevojčice ne može i ne smije svesti na čisti proceduralni formalizam u pristupu nadležnih tijela, pogotovo u situaciji kada postoje određene neuravnoteženosti u pristupu ocjene vjerojatnosti dostupnih dokaznih materijala. U pogledu drugog prigovora, Ustavni sud je razmatrao uvjete smještaja podnositelja u prihvatnom centru s aspekta moguće povrede čl. 23. st. 1. Ustava, kojim je propisano da nitko ne smije biti podvrgnut bilo kakvom obliku zlostavljanja, odnosno čl. 3 . Konvencije za zaštitu ljudskih prava i temeljnih sloboda, kojim je propisano da nitko ne smije biti podvrgnut mučenju ni nečovječnom ili ponižavajućem postupanju ili kazni. Sud je

87 Ustavni sud Republike Hrvatske, Odluka broj: U-IIIBi-1385/018 od 18. prosinca 2018., dostupno na: https://sljeme.usud.hr/Usud/Praksaw.nsf/C12570D30061CE54C125836800452D11/\$FILE/U-IIIBi1385-2018.pdf, pristupljeno: 20. rujna 2019.

88 Andrej Abramović, Lovorka Kušan i Goran Selanec. 
razmatrao posebno je li došlo do povrede ustavnih prava u odnosu na djecu, a onda i posebno u odnosu na punoljetne podnositelje. U pogledu uvjeta boravka djece u prihvatnom centru, Ustavni sud je utvrdio kako su uvjeti u kojima su boravila djeca bili prilagođeni njihovoj dobi, odnosno prikladni za djecu. Sud je konstatirao kako je djeci u centru „,bila osigurana redovita skrb i prehrana, djeca su se mogla igrati na čistom zraku i na travi, spavaonice nisu bile zaključane ni preko noći, obilazili su ih i psiholog i socijalni radnik“" (točka 27) ${ }^{89}$ Nadalje, Sud je utvrdio da zadržavanje stranaca u prihvatnim centrima mora biti poduzeto u dobroj vjeri i da ne smije prekoračiti razumno vrijeme potrebno kako bi se ostvarila svrha zbog koje je određeno. Mjera koja je primijenjena prema djeci, prema Zakonu o privremenoj i međunarodnoj zaštiti može trajati najdulje tri mjeseca, a u konkretnom je slučaju trajala dva mjeseca i 14 dana, što je opravdano provjerom identiteta i srodstva s odraslim podnositeljima, te sprečavanjem kaznenih djela vezanih uz trgovinu ljudima (točka 28.). U odnosu na punoljetne podnositelje, Ustavni je sud konstatirao kako prema stajalištu Europskog suda za ljudska prava (Popov protiv Francuske) pitanje može li se roditelj smatrati žrtvom zlostavljanja njegove djece ovisi o postajanju posebnih čimbenika, koji podnositeljevoj patnji daju značaj različit od emocionalne patnje, koja se povezuje s rođacima žrtava ozbiljnih povreda ljudskih prava. Relevantni elementi uključuju neposrednu blizinu obiteljskih veza i način na koji su vlasti odgovorile na roditeljske upite, a bit takve povrede itekako leži u reakciji nadležnih vlasti (točka 29). U odnosu na podnositelje Ustavni sud je utvrdio kako je njihovo zadržavanje u centru ,moglo stvoriti osjećaj bespomoćnosti, s osjećajima panike i frustracije, a zajednički boravak s djecom u centru na njih je imao olakšavajući značaj, pa prag koji je potreban za kršenje članka 3. Konvencije nije dosegnut" (točka 29.1.). Također, povodom razmatranja prigovora podnositelja da im je onemogućeno kvalitetno zastupanje u postupku za dobivanje međunarodne zaštite, Ustavni sud je utvrdio da je podnositeljima od trenutka ulaska u Republiku Hrvatsku bila osigurana besplatna pravna pomoć, da je do nešto zakašnjelog kontakta s odvjetnicom došlo unutar razumnog roka, uzevši u obzir brojnost podnositelja, osiguravanje njihovih potreba u prihvatnom centru, raspoloživost prevoditelja i drugog osoblja. Ustavni sud je utvrdio kako nije došlo do povrede čl. 23. st. 1. Ustava, odnosno čl. 3. Konvencije. Možemo zaključiti kako ova odluka Ustavnog suda predstavlja značajan doprinos i svojevrsni putokaz ponajprije praksi upravnih sudova u predmetima odlučivanja o zakonitosti mjere smještaja migranata u prihvatnim centrima.

Drugi predmet iz prakse Ustavnog suda prilično je recentan. Riječ je o odluci broj: U-III-557/2019 od 11. rujna 2019. ${ }^{90}$ kojom je usvojena ustavna tužba podnositeljice, državljanke Republike Irak, čiji je zahtjev za međunarodnu zaštitu odbijen kao neosnovan. Značaj ove iznimno bitne odluke ogleda se u tome da je Ustavni sud konstatirao kako nadležna tijela, odnosno MUP i upravni sudovi, ,nisu postupala na

89 Isto je utvrdio i Upravni sud u Osijeku u presudi broj: UsI-626/18-25 od 25. svibnja 2018.

90 Ustavni sud Republike Hrvatske, Odluka broj: U-III-557/2019 od 11. rujna 2019., dostupno na: https://sljeme.usud.hr/usud/praksaw.nsf/fOdluka.xsp?action=openDocument\&documentId=C12570D30 061CE54C125847400330C25, pristupljeno: 22. rujna 2019. 
način za koji bi se moglo reći da je u skladu s jamstvima koja štite prava iz čl. 23. st. 1. Ustava, odnosno čl. 3. Konvencije“" (točka 5.14.). Ustavni sud je uvažio ustavnu tužbu podnositeljice koja je svjedočila o pretrpljenom nasilju i zlostavljanju muških članova svoje obitelji u domovini, te je naredio nadležnim tijelima da u ponovljenom postupku otklone uočene nedostatke i omoguće podnositeljici da dokazuje svoju osobnu situaciju i okolnosti koje navodi kao razloge traženja međunarodne zaštite. Ovakvom je odlukom Ustavni sud otvorio vrata radikalnoj promjeni dosadašnje prakse upravnih sudova, koji odreda obiteljsko nasilje ne percipiraju kao razlog za odobravanje međunarodne zaštite. Međutim, Ustavni sud je u ovoj odluci izrijekom naglasio da se, zahvaljujući apsolutnom karakteru prava koje štiti, čl. 3. Konvencije „ne primjenjuje samo na opasnost koja proizlazi od pripadnika represivnog državnog aparata, već i na opasnost koja dolazi od osoba ili skupina osoba koje nisu pripadnici tog aparata" (točka 5.5.). Ustavni sud nije se složio sa zaključkom upravnih sudova da su podnositeljičine tvrdnje neuvjerljive. U tom kontekstu, Sud je ocijenio kako nadležna tijela nisu uzela u obzir u današnje vrijeme općepoznate činjenice da tjelesno, a pogotovo seksualno nasilje, odnosno silovanje, predstavlja iznimno jako traumatsko iskustvo koje ostavlja teške, odnosno razorne i dugotrajne posljedice u životu svake žrtve, te se stoga i u praksi Europskog suda za ljudska prava kvalificira kao zlostavljanje. Nadalje, jak osjećaj srama i straha, kao i još uvije prisutne brojne predrasude prema žrtvama takve vrste nasilja onemogućuju žrtve na prijavljivanje takvog nasilja i na traženje pomoći. Kada se navedene činjenice kumuliraju s kulturološkim kontekstom podnositeljičine situacije i sredine iz koja dolazi, tada je, po ocjeni Ustavnog suda, posve nerazumno smatrati da nije bilo razloga zbog kojih podnositeljica nije mogla otvoreno ranije govoriti o svojim traumama, i to još, što je ovdje bio slučaj, pred dvojicom muškaraca. Nadležni sudovi su stoga bili dužni ocjenu njezinih iskaza staviti u kontekst svih tih činjenica (točka 5.13.). Osim naredbe nadležnim tijelima da u ponovljenom postupku otklone uočene nedostatke, Ustavni sud je dao i svojevrsnu uputu nadležnim tijelima da pri tome detaljno razmotre aktualne činjenice o stanju u Iraku, posebno s aspekta zaštite žena žrtava obiteljskog nasilja, te prisutnosti mahrama, vodeći pri tome računa i o mogućnosti preseljenja u sigurne dijelove Iraka (točka 5.14.).

\section{INTEGRACIJA MIGRANATA U HRVATSKO DRUŠTVO - INSTITUCIONALNI OKVIR}

Integracija migranata u hrvatsko društvo je, na temelju zakonodavnog i regulatornog integracijskog okvira, područje koje je u nadležnosti nekoliko ministarstava (na čelu s Ministarstvom unutarnjih poslova), ureda, povjerenstava, a značajnu ulogu u ovom području svakako imaju i brojne nevladine organizacije.

Glavno tijelo zaduženo za opću implementaciju mjera migracijske politike jest Ministarstvo unutarnjih poslova. Sukladno čl. 76. st. 3. Zakona o međunarodnoj i privremenoj zaštiti, ovo Ministarstvo provodi aktivnosti za integraciju stranaca u društvo, koje uključuju izradu plana integracije, pružanje pomoći u ostvarivanju 
plana i nadzor nad izvršenjem plana. Ostala ministarstva uključena su u integraciju migranata u skladu sa svojim područjem rada: tako je, primjerice, pravo na socijalnu skrb u nadležnosti Ministarstva za demografiju, obitelj, mlade i socijalnu politiku, pravo na zdravstvenu zaštitu u nadležnosti Ministarstva zdravstva, pravo na obrazovanje u nadležnosti Ministarstva znanosti i obrazovanja itd.

Glavno koordinacijsko tijelo u području integracije jest Ured za ljudska prava i prava nacionalnih manjina Vlade Republike Hrvatske. Ova nadležnost Ureda proizlazi iz čl. 76. st. 5. Zakona o međunarodnoj i privremenoj zaštiti, prema kojemu Ured provodi koordinaciju svih ministarstava, nevladinih organizacija i drugih tijela koja sudjeluju u postupku integracije, u okviru Stalnog povjerenstva za provedbu integracije stranaca u hrvatsko društvo ${ }^{91}$ i pripadajuće Radne skupine koja izrađuje prijedloge strateških dokumenata u ovom području. ${ }^{92}$

Konačno, bitno je istaknuti kako važnu ulogu u implementaciji i nadzoru integracijske politike imaju brojne međunarodne organizacije (prije svega UNHCR, u skladu s Konvencijom o statusu izbjeglica), ali i brojne nevladine organizacije u Hrvatskoj (Hrvatski Crveni križ, Isusovačka služba za izbjeglice, Hrvatski pravni centar, Centar za mirovne studije, Udruga „MI“ - Split, Are You Syrious itd.). ${ }^{93}$

\section{INTEGRACIJA MIGRANATA U HRVATSKO DRUŠTVO - IZAZOVI I MOGUĆA RJEŠENJA}

Unatoč postojanju odgovarajućeg pravnog, kao i institucionalnog integracijskog okvira, dostupna istraživanja pokazuju kako implementacija navedenih okvira nije na zavidnoj razini.

Tako, primjerice, rezultati MIPEX-a - Indeksa razvijenosti politika integracije migranata ${ }^{94}$ za 2015 . godinu za Hrvatsku pokazuju kako Hrvatska ima tek polovično povoljne integracijske politike, odnosno s rezultatom 43/100 bodova Hrvatska je

91 Vlada Republike Hrvatske je 4. travnja 2013. imenovala predsjednika (ravnatelj Ureda za ljudska prava i prava nacionalnih manjina) i članove Stalnog povjerenstva za provedbu integracije stranaca $u$ hrvatsko društvo. Za članove su imenovani predstavnici resornih tijela nadležnih za područje obrazovanja, zdravstva, rada, socijalne politike, kulture, stanovanja, unutarnjih poslova, vanjskih poslova, regionalnog razvoja i fondova Europske unije, te Državnog ureda za Hrvate izvan domovine. U 2014. godini Povjerenstvo je prošireno predstavnicima iz Državnog ureda za obnovu i stambeno zbrinjavanje i Ureda za udruge Vlade Republike Hrvatske.

92 Radna skupina za operativnu provedbu zadaća Stalnog povjerenstva za provedbu integracije stranaca u hrvatsko društvo imenovana je 15. travnja 2013. od strane ravnatelja Ureda za ljudska prava i prava nacionalnih manjina. Primarni cilj Radne skupine bila je izrada Akcijskog plana za uklanjanje prepreka u ostvarivanju pojedinih prava iz područja integracije.

93 Uloga nevladinih organizacija uglavnom je vezana uz pružanje različitih oblika pomoći i podrške migrantima, u obliku provedbe tečajeva hrvatskog jezika i kulture, davanja pravnih savjeta o pravima i obvezama, pružanja pomoći u kontaktiranju institucija, pružanja psihološke podrške itd.

94 MIPEX - The Migration Integration Policy Indeks jest referentni vodič i interaktivni alat za procjenu, usporedbu i unapređenje integracijskih politika. Upotrebljavajući 148 različitih indikatora, MIPEX utvrđuje stupanj ostvarivanja jednakih prava i odgovornosti stanovnika jedne zemlje. Više o tome: http://mipex.eu. 
zauzela 30. mjesto od ukupno 38 država obuhvaćenih istraživanjem. Najvećim problemom pokazala se provedba zakona narušena diskrecijskim postupcima vlasti, zbog čega su migrantima uskraćena brojna prava. Kao slabe karike integracijskih strategija izdvojeni su: jezični tečajevi u svrhu uključivanja u tržište rada, pristup jezičnim tečajevima i učeničkim stipendijama, ciljana obrazovna podrška za djecu, zdravstvena zaštita, diskriminacija protiv državljana država koje nisu članice Europske unije i politička participacija. Stoga su neke od preporuka ovog istraživanja usmjerene upravo na područja obrazovanja, pohađanja jezičnih tečajeva u svrhu uključivanja u tržište rada, bolje zdravstvene zaštite, te političke participacije. ${ }^{95}$

Korisno je analizirati i rezultate istraživanja Europske komisije i OECD-a pod nazivom Indikatori o integraciji imigranata, ${ }^{96}$ koji zaista detaljno kompariraju integraciju migranata u 2018. godini u državama članicama Europske unije i OECD-a prema različitim indikatorima (ukupno njih 74), kao što su zapošljavanje, obrazovanje, zdravlje, participacija. Prema navedenom istraživanju, Hrvatska se nalazi u skupini zemalja u kojima se migranti kratko zadržavaju, odnosno samo prolaze kroz njih na putu za boljim životom. Što se tiče obrazovanja, vrlo nisko ili primarno obrazovanje ima 4 posto migranata, nisko ili sekundarno obrazovanje u Hrvatskoj ima 24 posto migranata, a visoko ili tercijarno obrazovanje ima 18 posto migranata. Istraživanje je također pokazalo kako u odnosu na domaće stanovništvo migranti općenito rade poslove za koje su prekvalificirani. Podaci za zaposlenost migranata u Hrvatskoj pokazuju kako je prošle godine bilo zaposleno 56 posto migranata, od kojih je 64 posto muškaraca. Njih 79 posto je visokoobrazovano, a 35 posto niskog obrazovanja, te 16 posto migranata radi posao za koji su prekvalificirani. Ukupno 28 posto migranata u Hrvatskoj živi ispod praga siromaštva. Podaci vezani uz diskriminaciju pokazuju kako je 3 posto migranata u Hrvatskoj potvrdilo sa su doživjeli neki oblik diskriminacije, što Hrvatsku smješta među zemlje u kojima ima najmanje diskriminiranih migranata. Ipak, u analizi rezultata indikatora integracije treba imati na umu da je prema ovom istraživanju u Hrvatskoj 13 posto migranata, odnosno općenito osoba rođenih izvan Hrvatske, ili ukupno 540.000 osoba.

Prema istraživanju Instituta za migracije i narodnosti, neodgovarajuća učinkovitost integracijske politike dijelom je i posljedica slabe suradnje nadležnih državnih i lokalnih tijela, te nevladinih organizacija, akademske zajednice i općenito profesionalaca involviranih u integraciju. ${ }^{97}$ Uspostavljanje konstruktivnog dijaloga nadležnih aktera kao sine qua non za unapređenje sustava integracije ističe se i od strane onih koji se svakodnevno susreću s izazovima i mogućnostima integracije migranata u praksi. ${ }^{98}$

95 Više o tome: http://www.mipex.eu/croatia; pristupljeno: 20. rujna 2019.

96 Settling in 2018. Indicators of Immigrant Integration, dostupno na: https://ec.europa.eu/migrantintegration/librarydoc/settling-in-2018-indicators-of-immigrant-integration, pristupljeno: 22. rujna 2019.

97 Institute for Migration adn Ethnic Studies, Integration of Migrants in the European Union with Reference to Croatia, op. cit. (bilj. 18), str. 10.

98 Vidi: Izvješće o radu Stalnog povjerenstva za provedbu integracije stranaca u hrvatsko društvo u 2017. godini, str. 4., dostupno na: https://pravamanjina.gov.hr/UserDocsImages/dokumenti/ Izvje\%C5\%A1\%C4\%87e\%20o\%20radu\%20Stalnog\%20povjerenstva_Integracija_2017\%2028.6.2018_. pdf, pristupljeno: 20. rujna 2019. 
Prepreke na putu kvalitetnije implementacije zakonodavnog okvira tiču se i podkapacitiranosti institucija državne i javne uprave, posebno centara za socijalnu skrb i Hrvatskog zavoda za zapošljavanje, te neodgovarajuće stručnosti u ovom području i nedovoljnog poznavanja jezika, s obzirom na to da institucije nemaju na raspolaganju dovoljan broj prevoditelja. ${ }^{99}$

Kvalitetnijoj implementaciji zakonodavnog okvira sasvim sigurno ne doprinose niti prisutni stavovi i predrasude prema migrantima u Hrvatskoj. Što se tiče stavova prema migrantima, do sada provedena (malobrojna) istraživanja u Hrvatskoj pokazuju da su stavovi prema migrantima u Hrvatskoj uglavnom negativni, te da postoje brojne predrasude i strahovi u kontekstu priljeva većeg broja migranata. Tako, primjerice, istraživanje koje su proveli Župarić-Iljić i Gregurović (2013.) na uzorku studenata Sveučilišta u Zagrebu pokazuje da veći doživljaj tražitelja azila kao društvene i kulturne prijetnje među studentskom populacijom imaju studenti koji studiraju tehničke znanosti, politički se pozicioniraju desno, uvjereni su vjernici ili su religiozni, te oni koji nemaju ili imaju samo jednog prijatelja stranca u Hrvatskoj. ${ }^{100}$ Obućina navodi kako su se stavovi o migrantima u Hrvatskoj drastično promijenili zahvaljujući „migrantskoj krizi“, o čemu svjedoči znatno povećanje (za $10 \%$ ) negativnih odgovora o migraciji evidentirano u razdoblju od proljeća 2015. do kraja 2015. godine. ${ }^{101}$ Rezultati istraživanja koje su Gregurović, Kuti i Župarić-Iljić (2016.) proveli na uzorku odraslih osoba stanovnika dvije najistočnije hrvatske županije pokazuju izraženu percepciju migrantskih radnika u okviru dimenzije kulturne prijetnje uz izražen značajan stupanj društvene distance. ${ }^{102} \mathrm{I}$ rezultati istraživanja o odnosu mladih ljudi prema tražiteljima azila koje su proveli Ajduković, Bakić, Stanković i Matić (2017.) potvrđuju postojanje umjereno izraženih predrasuda prema azilantima i umjerenu razinu percipirane prijetnje od azilanata. ${ }^{103}$

U skladu s navedenim, može se zaključiti kako su neophodni uvjeti kvalitetnije integracije migranata u Hrvatskoj (barem) sljedeći: 1) jačanje obrazovnog položaja migranata (pri čemu bi poseban naglasak trebalo staviti na razvijanje različitih modela učenja hrvatskog jezika za učenike osnovnih i srednjih škola, kao i na

99 Ibid.

100 Župarić-Iljić, D., Gregurović, M., „Stavovi studenata prema tražiteljima azila u Republici Hrvatskoj“, Društvena istraživanja, Vol. 22, No. 1, 2013.

101 Obućina navodi kako je prije ,migrantske krize“ $43 \%$ stanovništva imalo negativna stajališta o migrantima izvan Europske unije, a poslije krize postotak je iznosio 53 \%. Vidi: Bayrakli, E., Hafez, F. (eds.), European Islamophobia report 2015, Croatia - Vedran Obućina, str. 99, dostupno na: https:// books.google.hr/books?id=x27QCwAAQBAJ\&pg=PA95\&lpg=PA95\&dq=obucina+islamophobia +in+ croatia+2016\&source=bl\&ots=M5fRKo3WSl\&sig=ACfU3U1-yLMYttgbcwKeRimqyUhAPOPjEg\&hl$=\mathrm{hr} \& \mathrm{sa}=\mathrm{X} \& \mathrm{ved}=2 \mathrm{ahUKEwiGkrXCmPvlAhUENOwKHaktCSkQ6AEwBHoECAoQAQ \# v=onepage \& q}$ =obucina\%20islamophobia\%20in\%20croatia\%202016\&f=false, pristupljeno: 20. rujna 2019.

102 Gregurović, M., Kuti, S., Župarić-Iljić, D., ,Stavovi prema migrantskim radnicima i tražiteljima azila u istočnoj Slavoniji: dimenzije, odrednice i razlike“, Migracijske i etničke teme, Vol. 32, No. 1, 2016.

103 Ajduković, D., Bakić, H., Stanković, N., Matić, J., „Odnos mladih prema integraciji azilanata“, 25. godišnja konferencija hrvatskih psihologa-Psihologija u promociji i zaštiti ljudskih prava $i$ društvene pravednosti-Sažetci priopćenja / Ćubela Adorić, V., Franc, R., Kalebić Maglica, B., Nakić Radoš, S. (ur.). Zagreb: Hrvatsko psihološko društvo, 2017. 
razvijanje sustava stipendiranja učenika i studenata uključenih u visoko obrazovanje, ali i na razvijanje sustava edukacije i podrške obrazovnim djelatnicima); 2) jačanje socijalno-ekonomskog položaja migranata (pri čemu se kao nužnost ističe osiguravanje kvalitetnog savjetovanja migranata u okviru Hrvatskog zavoda za zapošljavanje, kao i uvođenje poreznih olakšica poslodavcima za zapošljavanje migranata, te razvijanje sustava educiranja poslodavaca o važnosti zapošljavanja migranata); 3) jačanje građanskih i kulturnih prava migranata (pri čemu se kao imperativ nameće osiguravanje edukacije za djelatnike raznih institucija, od djelatnika granične policije, preko policijskih službenika i liječnika, do djelatnika u obrazovanju i kulturi, ali i razvijeni sustav informiranja migranata o njihovim pravima i osiguravanje mjera za njihovu političku participaciju), te 4) jačanje zdravstvene zaštite migranata (pri čemu se kao prioritet ističe omogućavanje punog i pravednog pristupa zdravstvenom sustavu i zdravstvenoj zaštiti svim migrantima). Pri tome, smatramo kako ova nužna četiri uvjeta nije moguće kvalitetno ostvariti bez dva dodatna preduvjeta. Prvi je preduvjet vezan uz uočene stavove javnosti prema migrantima, te se odnosi na provedbu kvalitetne i dugoročne javne kampanje, usmjerene na senzibiliziranje javnosti prema migrantima. Drugi preduvjet odnosi se na poticanje suradnje između svih aktera uključenih u integraciju migranata, od državnih vlasti, preko regionalnih i lokalnih vlasti, do organizacija civilnog društva, akademske zajednice i općenito profesionalaca uključenih u integraciju. Javna kampanja, suradnja i dijalog ključ su unapređenja integracije migranata u hrvatsko društvo.

\section{LITERATURA}

\section{Knjige i članci}

1. Ajduković, D., Bakić, H., Stanković, N., Matić, J., „Odnos mladih prema integraciji azilanata“, 25. godišnja konferencija hrvatskih psihologa-Psihologija u promociji $i$ zaštiti ljudskih prava i društvene pravednosti - Sažetci priopćenja / Ćubela Adorić, V., Franc, R., Kalebić Maglica, B., Nakić Radoš, S. (ur.). Zagreb: Hrvatsko psihološko društvo, 2017.

2. Bayrakli, E., Hafez, F. (eds.), European Islamophobia report 2015, Croatia - Vedran Obućina, dostupno na: https://books.google.hr/books?id=x27QCwAAQBAJ\&pg=P A95\&lpg=PA95\&dq=obucina + islamophobia + in + croatia $+2016 \&$ source $=$ bl\&ots $=M$ 5fRKo3WSl\&sig=ACfU3U1-yLMYttgbcwKeRimqyUhAPOPjEg\&hl=hr\&sa=X\&v ed=2ahUKEwiGkrXCmPvlAhUENOwKHaktCSkQ6AEwBHoECAoQAQ\#v=onep age \&q=obucina $\% 20$ islamophobia $\% 20$ in $\% 20$ croatia $\% 202016 \& f=$ false

3. Božić, S., Kuti, S., „Europska politika integracije migranata: od standardiziranja mjera za zemlje Europske unije prema integracijskom servisu utemeljenom na društvenoznanstvenim spoznajama“", Revija za sociologiju, 48, 1, 2018.

4. Council of Europe, Human rights aspects of immigrant and refugee integration policies, Issue Paper published by the Special Representative of the Secretary General on migration and refugees, 2019., dostupno na: https://rm.coe.int/168093de2c, 
5. Esser, H., Does the New Immigration Require a New Theory of Intergenerational Integration?, Working paper, Mannheim: MZES 2003, dostupno na: http://citeseerx. ist.psu.edu/viewdoc/download?doi=10.1.1.197.2189\&rep=rep1\&type=pdf

6. European Council of Refugees and Exiles, Position on the Integration of Refugees in Europe, 2002., dostupno na: https://www.ecre.org/wp-content/uploads/2016/07/ ECRE-Position-on-the-Integration-of-Refugees-in-Europe_December-2002.pdf

7. Gregurović, M., Kuti, S., Župarić-Iljić, D., ,Stavovi prema migrantskim radnicima i tražiteljima azila u istočnoj Slavoniji: dimenzije, odrednice i razlike“, Migracijske $i$ etničke teme, Vol. 32, No. 1, 2016.

8. Heckmann, F., Bosswick, W., Integration of Migrants: Contribution of Local and Regional Authorities, European Foundation for the Improvement of Living and Working Conditions, 2006., dostupno na: https://www.researchgate.net/ publication/297802930_Integration_of_Migrants_Contribution_of_Local_and_ Regional_Authorities

9. Institute for Migration and Ethnic Studies, Integration of Migrants in the European Union with Reference to Croatia: Position Paper of the Institute for Migration and Ethnic Studies, 2016., dostupno na: http://www.imin.hr/en/c/document_library/get_ file?uuid=23cb77ac-e5d4-4f1e-8fce-b2e040512833\&groupId=10156

10. Kirişci, K., „,Three Way Approach“ to Meeting the Challenges of Migrant Incorporation in the European Union: Reflections from a Turkish Perspective, CARIM Research Reports 2008/03, European University Institute, Robert Schuman Centre for Advanced Studies, 2008.

11. Klarenbbek, L. M., „Reconceptualising 'integration as a two-way process'“, Migration studies, mnz033, 2019., dostupno na: https://doi.org/10.1093/migration/mnz033

12. Penninx, R., „Integration of Migrants: Economic, Social, Cultural and Political Dimensions", The new demographic regime, dostupno na: https://www.researchgate. net/publication/254920820_Integration_of_migrants_Economic_social_cultural_ and_political_dimensions

13. Penninx, R., Garcés-Mascarenas, B., „The Concept of Integration as an Analytical Tool and as a Policy Concept“, u: Garcés-Mascarenas, B., Penninx, R. (Editors), Integration Process and Policies in Europe. Context, Levels and Actors, IMISCOE Researches Series, Springer Open, 2016.

14. Robinson, V., „Defining and measuring successful refugee integration“, u: ECRE, Proceedings of ECRE International Conference on Integration of Refugees in Europe, Antwerpen, November 1998, dostupno na: http://repesitory.forcedmigration.org $>$ pdf

15. Smerdel, B., Sokol, S., Ustavno pravo, Narodne novine, Zagreb, 2009.

16. Župarić-Iljić, D., Gregurović, M., „Stavovi studenata prema tražiteljima azila u Republici Hrvatskoj“, Društvena istraživanja, Vol. 22, No. 1, 2013.

\section{Pravni propisi}

1. Ustav Republike Hrvatske, Narodne novine br. 56/90., 135/97., 8/98., 113/00., 124/00., 28/01., 41/01., 55/01., 76/10., 85/10., 5/14. 
2. Opća deklaracija o ljudskim pravima, Narodne novine - Međunarodni ugovori, br. 2/09.

3. Međunarodni pakt o građanskim i političkim pravima, Narodne novine-Međunarodni ugovori, br. 12/93., 7/95. i 11/95.

4. Međunarodni pakt o gospodarskim socijalnim i kulturnim pravima, Narodne novine - Međunarodni ugovori, br. 12/93.

5. Konvencija protiv mučenja i drugih okrutnih, neljudskih i ponižavajućih postupanja i kažnjavanja, Narodne novine - Međunarodni ugovori, br. 12/93., 2/05., 3/07.

6. Konvencija o pravima djeteta, Narodne novine - Međunarodni ugovori, br. 12/93.

7. Konvencija Vijeća Europe za zaštitu ljudskih prava i temeljnih sloboda, Narodne novine - Međunarodni ugovori, br. 18/97., 6/99. - pročišćeni tekst, 8/99. - ispravak, 14/02., 13/03., 9/05., 1/06., 2/10.

8. Europska konvencija za sprečavanje mučenja i neljudskog ili ponižavajućeg postupanja ili kažnjavanja, Narodne novine - Međunarodni ugovori, br. 14/97.

9. Konvencija o statusu izbjeglica i pripadajući protokol, Narodne novine-Međunarodni ugovori, br. 12/93.

10. Zakon o strancima, Narodne novine, br. 130/11., 74/13., 69/17., 46/18.

11. Zakon o hrvatskom državljanstvu, Narodne novine, br. 53/91., 70/91., 28/92., 113/93., 4/94., 130/11., 110/15.

12. Zakon o međunarodnoj i privremenoj zaštiti, Narodne novine, br. 70/15., 127/17.

13. Zakon o socijalnoj skrbi, Narodne novine, br. 157/13., 152/14., 99/15., 52/16.

14. Zakon o doplatku za djecu, Narodne novine, br. 94/01., 138/06., 107/07., 37/08., 61/11., 112/12., 82/15.

15. Zakon o rodiljnim i roditeljskim potporama, Narodne novine, br. 85/08., 110/08., 34/11., 54/13., 152/14.

16. Zakon o obrazovanju u osnovnoj i srednjoj školi, Narodne novine, br. 87/08., 86/09., 92/10., 105./10. - ispravak, 90/11., 16/12., 86/12., 94/13., 152/14.

17. Akcijski plan za uklanjanje prepreka u ostvarivanju pojedinih prava u području integracije stranaca za razdoblje od 2013. do 2015. godine, dostupno na: https:// pravamanjina.gov.hr/UserDocsImages/arhiva/30092013/Akcijski\%20plan\%20 za\%20uklanjanje\%20prepreka\%20u\%20ostvarivanju\%20pojedinih\%20prava\%20 u\%20podru\%C4\%8Dju\%20integracije \%20stranaca\%20za\%20razdoblje\%20od\%20 2013\%20do\%202015\%20godine.pdf

18. Akcijski plan za integraciju osoba kojima je odobrena međunarodna zaštita za razdoblje od 2017. do 2019. godine, dostupno na: https://pravamanjina.gov.hr/ UserDocsImages/dokumenti/AKCIJSKI\%20PLAN\%20ZA\%20INTEGRACIJU\%20 2017-2019.pdf

19. Izvješće o radu Stalnog povjerenstva za provedbu integracije stranaca u hrvatsko društvo u 2017. godini, str. 4., dostupno na: https://pravamanjina.gov.hr/UserDocsImages/ dokumenti/Izvje\%C5\%A1\%C4\%87e\%20o\%20radu\%20Stalnog\%20povjerenstva_ Integracija_2017\%2028.6.2018_.pdf 
Izv. prof. dr. sc. Anita Blagojević: Pravni i institucionalni okvir integracije migranata u hrvatsko društvo Zbornik radova Pravnog fakulteta u Splitu, god. 57, 3/2020, str. 707-737

20. Migracijska politika Republike Hrvatske za razdoblje od 2013. do 2015. godine, Narodne novine, br. 27/13.

21. Nacionalni program zaštite i promicanja ljudskih prava za razdoblje od 2013. do 2016. godine, dostupno na: https://pravamanjina.gov.hr/UserDocsImages/dokumenti/ Nacionalni\%20program \%20za\%c5\%a1tite\%20i\%20promicanja\%20ljudskih $\% 20$ prava\%20za\%20razdoblje\%20od\%202013.\%20do\%202016.\%20godine.pdf

22. Povelja Europske unije o temeljnim pravima, Službeni list Europske unije, C 202/390, 2016., dostupno na: https://eur-lex.europa.eu/legal-content/HR/TXT/ PDF/?uri=CELEX:12016P/TXT\&from $=E N$

23. Pročišćene inačice Ugovora o Europskoj uniji i Ugovora o funkcioniranju Europske unije, 2010/C 83/01, dostupno na: http://www.mvep.hr/custompages/static/hrv/files/ pregovori/111221-lisabonski-prociscena.pdf

24. Tampere European Council 15 and 16 October 1999, Presidencial Conclusions, dostupno na: https://www.consilium.europa.eu/media/21059/tampere-europeancouncil-presidency-conclusions.pdf

25. Treaty of Amsterdam amending the Treaty on European Union, the Treaties establishing the European Communities and certain related act, dostupno na: https:// eur-lex.europa.eu/legal-content/HR/TXT/?uri=CELEX:11997D/TXT

26. The Stockholm Programme - An Open and Secure Europe Serving and Protecting Citizens, 2010/C 115/01, dostupno na: https://eur-lex.europa.eu/LexUriServ/ LexUriServ.do?uri=OJ:C:2010:115:0001:0038:EN:PDF

27. A Common Agenda for an Integration Framework for the Integration of ThirdCountry Nationals in the European Union (2005), dostupno na: https://eur-lex.europa. eu/LexUriServ/LexUriServ.do?uri=COM:2005:0389:FIN:EN:PDF

28. The Common Basic Principles for Immigrant Integration Policy in the European Union (2004), dostupno na: https://www.eesc.europa.eu/resources/docs/commonbasic-principles_en.pdf

29. Action programme in favour of migrants workers and their families, 14 December 1974, dostupno na: http://aei.pitt.edu/1278/1/action_migrant_workers_COM_74_2250.pdf

30. Action Plan on the Integration of Third-country Nationals, $\operatorname{COM}(2016) 377$, dostupno na: https://ec.europa.eu/home-affairs/sites/homeaffairs/files/what-we-do/policies/ european-agenda-migration/proposal-implementation-package/docs/20160607/ communication_action_plan_integration

31. Communication from the Commission to the Council, the European Parliament, the European Economic and Social Committee and the Committee of the Regions on immigration, integration and empolyment, COM (2003) 336 final, dostupno na: https://eur-lex.europa.eu/legal-content/EN/TXT/HTML/?uri=CELEX:52003DC033 $6 \&$ from $=\mathrm{EN}$

32. Communication from the Commission to the European Parliament, the Council, the European Economic and Social Committee of the Regions: European Agenda for the Integration of Third-Country Nationals, COM (2011), dostupno na: https:// www.km.gov.lv/uploads/ckeditor/files/Sabiedribas_integracija/Treso_valstu_pilsoni/ Dokumenti/Eiropas\%20programmma\%20TVP\%20integr\%C4\%81cijai\%202011.pdf 
33. Communication from the Commission to the Council and the European Parliament on a Community Immigration Policy, COM/2000/0757, dostupno na: https://eur-lex. europa.eu/legal-content/EN/TXT/?uri=celex:52000DC0757

34. Communication from the the Commission to the Council, the European Parliament, the European Economic and Social Committee and the Committee of the Regions on Immigration, Integration and Employment, COM (2003) 336, dostupno na: https:// eur-lex.europa.eu/LexUriServ/LexUriServ.do?uri=COM:2003:0336:FIN:EN:PDF

35. Communication from the Commission to the European Parliament, the Council, the European Economic and Social Committee and the Committee of the Regions: An open and secure Europe: making it happen, dostupno na: https://ec.europa.eu/homeaffairs/sites/homeaffairs/files/e-library/documents/basic-documents/docs/an_open_ and_secure_europe_-_making_it_happen_en.pdf

36. Communication from the Commission to the European Parliament, the Council, the European Economic and Social Committee and the Committee of the Regions: a European Agenda on Migration, dostupno na: https://ec.europa.eu/anti-trafficking/ sites/antitrafficking/files/communication_on_the_european_agenda_on_migration_ en.pdf

37. Settling in 2018. Indicators of Immigrant Integration, dostupno na: https://ec.europa. eu/migrant-integration/librarydoc/settling-in-2018-indicators-of-immigrantintegration

\section{Sudska praksa}

1. Ustavni sud Republike Hrvatske, Odluka broj: U-IIIBi-1385/018 od 18. prosinca 2018., dostupno na: https://sljeme.usud.hr/Usud/Praksaw.nsf/C12570D30061CE54 C125836800452D11/\$FILE/U-IIIBi-1385-2018.pdf

2. Ustavni sud Republike Hrvatske, Odluka broj: U-III-557/2019 od 11. rujna 2019. dostupno na: https://sljeme.usud.hr/usud/praksaw.nsf/fOdluka.xsp?action=openDoc ument\&documentId=C12570D30061CE54C125847400330C25 


\section{LEGAL AND INSTITUTIONAL FRAMEWORK FOR THE INTEGRATION OF MIGRANTS INTO CROATIAN SOCIETY}

It is well known that the phenomena of migrations is becoming increasingly relevant in the last decades. Especially from 2015 the refugess crisis in Europe has prompted numerous discussions about migration, refugees, integration and similar issues, and that is why this paper aims to contribute to professional and public debate on the issue of the integration of migrants into Croatian society. The paper consists of five parts. After the introductory part, in the second part of the paper we give a theoretical framework of the concept of integration of migrants, that is we give an overview of the (still unsuccesful) finding of the unique definition of the term integration of migrants. In the third part of the paper we present an overview of legal framework of the Republic of Croatia regarding integration of migrants. In this context, we analyse the relevant provisions of the Constitutution of the Republic of Croatia, relevant ratified international treaties, relevant national laws and regulations, as well as relevant case-law of the Constitutional Court of the Republic of Croatia. Having in mind that the Republic of Croatia has harmonized its legislation with the asquis communaitaire of the European Union and it is a Member States of the European Union, the special attention in this part of the paper is dedicated to the European Union framework for the integration of migrants. The fourth part of the paper deals with the institutional framework of the Republic of Croatia for the integration of migrants, and here we emphasize that the area of the integration of migrants, on the basis of legislative and regulatory framework, is under the jurisdiction of several ministries (headed by the Ministry of the Interior), offices, commissions, while the important role in this area certainly belongs to the numerous non-governmental organizations. Finally, in the fifth and also final part of the paper we make some recommendations for the further development of the integration policy of the Republic of Croatia.

Key words: integration, migrants, society, the Republic of Croatia 